\title{
THE ÁGUAS CLARAS CU-SULFIDE \pm Au DEPOSIT, CARAJÁS REGION, PARA, BRAZIL: GEOLOGICAL SETTING, WALL-ROCK ALTERATION AND MINERALIZING FLUIDS
}

\author{
CINTIA MARIA GAIA DA SILVA* \& RAIMUNDO NETUNO VILLAS**
}

\begin{abstract}
RESUMO . O DEPÓSITO DE SULFETOS DE Fe-Cu \pm Au DE ÁGUAS CLARAS, REGIÃO DE CARAJÁS, PARÁ, BRASIL: CONTEXTO GEOLÓGICO, ALTERAÇÃO HIDROTERMAL E FLUIDOSMINERALIZANTES A mineralização primária do depósito de Águas Claras (DAC), localizado na porção central da Serra dos Carajás, ocorre em veios de quartzo ao longo de uma zona de cisalhamento rúptil a rúptil-dúctil, de direção geral NE-SW e mergulhos sub-verticais. Essa zona corta rochas sedimentares siliciclásticas da Formação Águas Claras e sills básicos arqueanos. O enriquecimento supergênico é uma feição comum mesmo a profundidades de até $200 \mathrm{~m}$, onde os sulfetos encontram-se ainda parcialmente preservados.

Foram identificados vários tipos de alteração hidrotermal relacionados à mineralização como sericitização, turmalinização, argilização, silicificação, carbonatação e cloritização, este último o mais característico do depósito. Os veios de quartzo apresentam texturas maciça, em pente, em pluma, fantasma, brechada e de deformação.

A mineralização é dominada por sulfetos de $\mathrm{Fe}$ e $\mathrm{Cu} \pm \mathrm{Au}$ com quantidades subordinadas de minerais de $\mathrm{Zn}$ e W. As rochas encaixantes apresentam-se intensamente venuladas próximo à zona principal de cisalhamento. Pirita e calcopirita são as fases metálicas principais, com esfalerita e arsenopirita ocorrendo subordinamente. Os óxidos estão representados por magnetita, hematita e ferberita. O Au, apesar de não ter sido observado, faz parte da paragênese primária associado comumente à arsenopirita e calcopirita (Soares et al. 1994). A paragênese pirite-magnetita-hematita em equilíbrio indica condições relativamente oxidantes de precipitação com faixas representativas de fo2 e fsa entre $10^{-29}-10^{-23}$ atm e $10^{-9}-10^{-4}$ atm, respectivamente. Os dados microtermométricos indicaram soluções aquosas salinas provavelmente

correspondendo ao sistema $\mathrm{NaCl}-\mathrm{CaCl}_{2}-\mathrm{MgCl}_{2}-\mathrm{H}_{2} \mathrm{O}$, com temperaturas mínimas de homogeneização dos fluidos entre 360 e $100^{\circ} \mathrm{C}$, sendo a faixa de $190-160^{\circ} \mathrm{C}$ a mais freqüente. As variações de salinidade nas inclusões bifásicas estão entre o equivalente de $0,53 \mathrm{e}>23,5 \%$ em peso de $\mathrm{NaCl}$. As inclusões trifásicas apresentaram salinidades da ordem do equivalente a 30-45\% em peso de NaCl. Fluidos com diferentes salinidades aprisionados no intervalo de $360-160^{\circ} \mathrm{C}$ podem significar a ocorrência de eventos cíclicos na deposição mineral, enquanto que fluidos de baixas salinidade e temperatura $\left(130-100^{\circ} \mathrm{C}\right)$ podem ser produtos de soluções mais tardias na evolução do sistema ou mistura com águas meteóricas. $\mathrm{O}$ DAC é controlado estruturalmente e formado a profundidades rasas consistentes com os dados termométricos, as texturas de preenchimento dos veios e o baixo grau metamórfico das rochas hospedeiras. O sistema de veios possui características texturais de que foi formado através de pulsos recorrentes com várias gerações de quartzo que refletem a contemporaneidade com a associação dos sulfetos e a variação na salinidade dos fluidos.
\end{abstract}

Palavras-chave: Mineralização de sulfetos de $\mathrm{Cu}-\mathrm{Fe} \pm \mathrm{Au}$; sistema de veios de quartzo; zona de cisalhamento; alteração hidrotermal; inclusões fluidas.

ABSTRACT The Águas Claras deposit (ACD) is located in the central part of the Carajás ridge, Pará State, Brazil. Primary sulfide mineralization occurs in quartz veins emplaced along a brittle to brittle-ductile, NE-SW-striking shear zone with subvertical dips. This zone cross-cuts Archean siliciclastic sedimentary rocks of the Águas Claras Formation and basic sills. Supergene enrichment is a common feature even at depths down to $200 \mathrm{~m}$ where the sulfides are still partially preserved.

Petrographic studies of the wall rocks and quartz veins allowed the identification of an intense hydrothermal alteration, characterized by chloritization, serialization, tourmalinization, silicification, argillization and carbonation, the first being the most widespread process. Texturally the vein quartz shows buck, comb, feather, phantom, breccia and deformation features.

$\mathrm{Fe}-\mathrm{Cu}$ sulfides $\pm \mathrm{Au}$ are the main ore minerals with minor $\mathrm{Zn}$ and $\mathrm{W}$. Pyrite and chalcopyrite are the dominant sulfides with subordinate sphalerite and arsenopyrite. The oxide phases are represented by magnetite, hematite and ferberite. Au was not observed but its occurrence has been reported in close association with arsenopyrite and chalcopyrite (Soares et al. 1994).

The equilibrium assemblage pyrite-magnetite-hematite indjcates that relatively oxidizing conditions prevailed during the main mineralization stage with fo 2 and fs 2 ranges of $10^{-29}-10^{-23}$ atm and $10^{-9}-10^{-4}$ atm, respectively. The microthermometric data showed that the mineralizing fluids were essentially saline aqueous solutions corresponding to the $\mathrm{NaCl}-\mathrm{CaCl}_{2}-\mathrm{MgCl}_{2}-\mathrm{H}_{2} \mathrm{O}$ system. Homogeneization temperatures were found to be between 360 and $100^{\circ} \mathrm{C}$, although the most frequent range was $190-160^{\circ} \mathrm{C}$. Two-phase inclusions presented salinity variations from 0.53 to $>$ $23.5 \mathrm{wt}$. $\% \mathrm{NaCl}$ equiv. whereas the halite-bearing ones showed salinities of $35-45 \mathrm{wt}$. \% NaCl equiv. The changes in salinity at high to moderate temperatures $\left(360-160^{\circ} \mathrm{C}\right)$ may represent cyclic events of the mineral deposition. On the other hand, low-salinity, low-temperature $\left(130-100^{\circ} \mathrm{C}\right)$ fluid samples may represent later evolving solutions of the system or mixing with meteoric water.

The ACD is structurally controlled and was formed at low depths consistent with the thermal regime, vein filling textures and low grade metamorphism of the country rocks. The vein system shows textural features that have been interpreted as the result of repeated pulses with multiple generations of quartz, sulfide assemblages and fluids of different salinities.

Keywords: Fe-Cu-sulfide \pm Au mineralization; vein quartz system; shear zone; wall-rock alteration; fluid inclusions

INTRODUCTION Expressive reserves of iron, manganese, copper, gold, aluminum, tungsten and nickel render the Carajás region one of the most important mineral provinces in the world. Its gold potential has attracted prospectors to the region in such a profusion that in the early 1980 there were approximately 40,000 people just in one garimpo (Serra Pelada) - indeed the most spectacular example of gold digger migration ever recorded anywhere in the Amazon. The interest for gold has also attracted many mining companies. DOCEGEO -a subsidiary of the largest Brazilian mining company (Companhia Vale do Rio Doce - CVRD) - in particular has carried out an intensive exploration program for quite a long time in the search for gold. Such an effort resulted in the discovery of the Águas Claras deposit (ACD) in 1985 at about the same time that the Igarapé Bahia gold mine had come true. However the ACD has a small tonnage which is far from meeting the company needs for supplying additional ore to the Igarapé Bahia gold-producing plant. The highest gold contents are found in the supergene profile where processes of laterization and gossanization have been decisive to the economic concentration of this precious metal which is present at depths associated with hypogene sulfides.
The ACD is located in the central part of the Carajás Ridge, north of the Carajás Mineral Province, at approximately $28 \mathrm{~km}$ southeast of the Igarapé Bahia gold mine and ${ }_{\mathrm{x}}$ at $8 \mathrm{~km}$ southwest of the Igarapé Azul manganese mine (Fig. 1). The Aguas Claras mineralization occurs in a NE-SW trending shear zone that hosts a network of veins dominantly composed of quartz with subordinate amounts of oxides, sulfides and other silicates. Reserves are estimated at 9,531,550 tons of ore with an average $\mathrm{Au}$ grade of $2.43 \mathrm{~g} / \mathrm{ton}$ and a cut-off grade of $1 \mathrm{ppm}$ gold (Medeiros Filho, personal communication).

This paper is tailored to serve the dual purpose of (1) describing the geology of the Aguas Claras deposit, its host rocks and the types of hydrothermal alteration, and (2) characterizing the fluids from which the ore was precipitated. The sources of the mineralizing fluids are still unknown but the neighboring Paleoproterozoic Carajás granite seems to be a feasible alternative (Mougeot et al. 1996b). Unfortunately the scarcity of data on both the mineralization age and the isotopic composition of the fluids leaves the subject wide open to several hypotheses.

The present investigation neither carried out analytical work on gold nor studied its mode of occurrence and distribution. Eventual data 
here presented are based on Docegeo's internal reports and on papers recently submitted to publication by other authors.

REGIONAL GEOLOGICAL SETTING The Carajás region mostly coincides with the eastern block of the Central Amazonian province of the Amazon Craton (Teixeira et al. 1989). This block became tectonically stable around $1.9 \mathrm{Ga}$ and is made up of Archean and Paleoproterozoic rocks partially overlain by volcanic and sedimentary sequences. The Carajás region itself consists of granite-greenstone terrains and volcano-sedimentary sequences that have been separated into several lithostratigraphic units such as the Andorinhas Supergroup, the Xingu Complex, the Sapucaia Group, the Luanga and Serra Azul ultramafic massifs, the Itacaiúnas Supergroup, TTG suites, the granitic Plaque Suite and the Rio Fresco Group (Docegeo 1988; Araújo et al. 1988). Geochronological data show ages ranging from 2.86 to 2.50Ga for these units (Machado et al 1991) most of which are cut by anorogenic Paleoproterozoic granites that have been dated between 1.88 and 1.6 Ga (Dali' Agnol et al. 1994). All rocks but the anorogenic granites have been affected by medium to low grade metamorphism. Higher grade metamorphic rocks can be locally found such as the Pium Complex granulites.

Tectonically the Carajás region is included in the Itacaiúnas shear belt (Araújo et al. 1988) which has been divided into two distinct structural segments. The south segment is characterized by an imbrication of shear zones that caused both the uplifting of lower crustal granulites and the lenticular shaping of different lithologic units. The north segment, where the Aguas Claras deposit is located, is represented by a positive flower structure that encompasses the rocks of the Carajás basin. This structure is associated with a sinistrai strike-slip fault system in which the NW-SE trending Carajás and Cinzento faults are the most remarkable features.

The formation and subsequent inversion of the Carajás basin were set forth during an Archean thermo-tectonic event and resulted from kinetic movements that evolved from transtension to transpression (Costa et al. 1990). During Paleoproterozoic times the region experienced a thermal event responsible for the emplacement of several anorogenic granitic stocks and batholiths some of which were mineralized with Sn or W.

THE GEOLOGY OF THE ÁGUAS CLARAS DEPOSIT The ACD is characterized by a $\mathrm{Cu} \pm \mathrm{Au}$ hydrothermal mineralization hosted by extensional quartz veins that have been formed along britte shear zones with a strong gravitational component (Soares et al. 1994). Rocks of the Grão-Pará and Igarapé Bahia groups, the Águas Claras Formation as well as igneous intrusions of both basic and acid composition crop out in its surroundings. Docegeo (1988) considers the Igarapé Bahia Group as an independent lithostratigraphic unit but Araújo et al. (1991) included it in the Grão-Pará Group. Regarding the basic intrusions, the dikes and sills are not represented in the geologic map (Fig. 1) since they have not been yet properly mapped.

The Grão-Pará Group is composed of the Carajás Formation (BIF) which is sandwiched by two metabasic units locally associated with felsic rocks dated at $2758 \pm 78 \mathrm{Ma}$ (Wirth et al. 1986). Supergene alteration on the Carajás Formation has turned it into abundant iron ore of exceptional high quality. The coeval Igarapé Bahia Group is made up of intermediate to acid pyroclastic rocks (breccias and tuffs) and basic flows and sills, as well as fine-grained, laminated sedimentary rocks interbedded with iron formations. These rocks host an exhalative low grade $\mathrm{Fe}-\mathrm{Cu}$ sulfide mineralization with subordinate amounts of $\mathrm{Mo}, \mathrm{Ag}$ and $\mathrm{Au}$. However, supergene enrichment caused the gold to be concentrated into economic reserves which are presently mined (Igarapé Bahia mine) with a Au production of about 8 ton/year.

The Rio Fresco Group has been redefined in the Carajás region as the Águas Claras Formation (Araújo et al. 1988) which is the most widespread lithologic unit present in the deposit area. These authors consider the Águas Claras Formation as the upper unit of the Grão-Pará Group. Based on facies, stratigraphic and structural studies it has been considered to represent a prograde sedimentary megacycle (Nogueira et al. 1994) composed of shelf deposits (lower unit) and seashore and stream deposits (upper unit). Basic bodies cut the Aguas Claras Formation as dikes with NNE-SSW and NW-SE directions (Pinheiro et al. 1991; Nogueira et al. 1992) and sills (Barros et al. 1994a). Radiometric data yielded a $\mathrm{Pb}-\mathrm{Pb}$ value of $2645 \pm 12 \mathrm{Ma}$ for one of these sills (Dias et al. 1996) which is taken as the minimum age of that formation in fair agreement with U-Pb dating of $2708 \pm 37$ Ma obtained by Mougeot et al. (1996a).

The Serra dos Carajás batholith which is intrusive into the Águas Claras Formation occurs about $4 \mathrm{~km}$ west of the ACD. This igneous body has been dated at $1.88 \mathrm{Ga}$ (Machado et al. 1991) and consists mainly of syeno- and monzogranites that host uneconomic $\mathrm{Cu} \pm \mathrm{Mo}$ sulfide-bearing veins of hydrothermal derivation.

Ferruginous lateritic crust associated or not with gossans occurs in the flat topographic highs of the ACD. Gossan bodies have been Docegeo's prime target for gold exploration.

Studies carried out by Pinheiro et al. (1991), Costa (1992) and Nogueira et al. (1994) in the ACD vicinity recorded a NW-SE trending lineament that forms the Carajás fault compressive duplex and controls the course of the Águas Claras creek as the most remarkable structural feature. The deformational regime was brittle-ductile and resulted from oblique movements with strong sinistrai directional components represented by vertical shear zones, folds and thrusts. The main fault sets strike NE-SW, NW-SE and N-S.

THE MINERALIZED ZONE The ACD primary sulfide mineralization is found in two sets of hydrothermal quartz veins formed along a brittle to brittle-ductile NW-SE trending shear zone. These two sets have tabular geometry and are referred to as Body F-15 and Body $\mathrm{F}-23$ by Docegeo. They show general trends of $\mathrm{N} 20^{\circ} \mathrm{E}$ and $\mathrm{N} 60^{\circ} \mathrm{E}$ respectively with steep dips $\left(>70^{\circ}\right)$ to NW and SE (Fig. 2).

The shear zone cuts both the Águas Claras Formation and the gabbroic dikes and sills causing apparent displacements of up to 115 $\mathrm{m}$. The $\mathrm{Fe}-\mathrm{Cu}$ sulfide $\pm \mathrm{Au}$ mineralization occurs along fault planes which put the sedimentary and the basic rocks in lateral contact.

Host Rocks In this section the host rocks that underwent weak hydrothermal alteration and preserve most of their primary textural and compositional characteristics will be described.

THE SEDIMENTARY SEQUENCE Drill-hole cores show the dominance of quartz-arenites over siltstones and claystones at the vein system surroundings. The pellitic types were always observed as upper layers in bodies F-15 and F-23 being over $60 \mathrm{~m}$ thick. They display a reddish to violet color, plane-parallel lamination and frequent finegrained sandstone intercalations.

The quartz-arenites vary from whitish-greenish gray in deeper levels to reddish brown in the oxydation zone. They are fine to coarse-grained and apparently massive. Quartz (90-95\%), lithic fragments, muscovite and heavy minerals are the main detrital constituents, being sedimentologically classified as mature quartz-arenites. The quartz grains $(0.12$ to $0.5 \mathrm{~mm}$ in diameter $)$ are in general monocrystalline with moderate to strong wavy extinction. The original roundness and sorting are masked by syntaxial overgrowth of authigenic quartz that turns the grains angular to subangular. However, in a few samples a film of iron oxide envelops some grains outlining an original good roundness and moderate sorting. Paleolines of heavy minerals consist of euhedral to anhedral zoned zircon grains and chloritized tourmaline. The only lithic fragments in the deposit were of chert, but on profiles along a nearby road other types (claystone, siltstone, sandstone and volcanic rocks) have been described (Costa 1992; AnaisseJr. 1995).

Generally the quartz-arenites are fractured in several directions with quartz, chlorite, tourmaline and sulfides filling the fracture planes. The fractures, some of which showing millimetric displacements, have changed the quartz grains into subgrains by recovery processes.

METABASIC HYPABYSSAL ROCKS Vertical sections of bodies F-15 and F-23 revealed dikes and sills with apparent thicknesses of $20-30 \mathrm{~m}$ and $110-130 \mathrm{~m}$ respectively that are intrusive into the sedimentary sequence. The descriptions below refer to the sills but the dikes have been similarly altered by hydrothermal fluids.

The rocks have gabbroic composition, homogeneous primary texture and granulation varying from fine near the contacts to coaser towards the center of the sills. Ophitic and subophitic textures are well preserved. Porphyritic varieties are also observed locally showing magnetite and plagioclase phenocrysts. The dominant color is dark green but it changes to reddish and whitish hues in the weathering zone and to pale green when hydrothermally altered.

Less altered rocks have been studied by Barros et al. (1994a). They described clinopyroxene, labradorite(?) and titanomagnetite as the essential minerals of the primary paragenesis and apatite, quartz, and zircon as the most common accessory phases. Hornblende may be present but it represents a high-temperature secondary mineral. Actinolite, chlorite, epidote, titanite, opaques, sericite and carbonates are also described as products of a hydrothermal-metamorphic event to which the term metagabbro is associated.

In the present study the rock that better preserves the primary mineralogical composition is a gabbro made up of hornblende, py- 


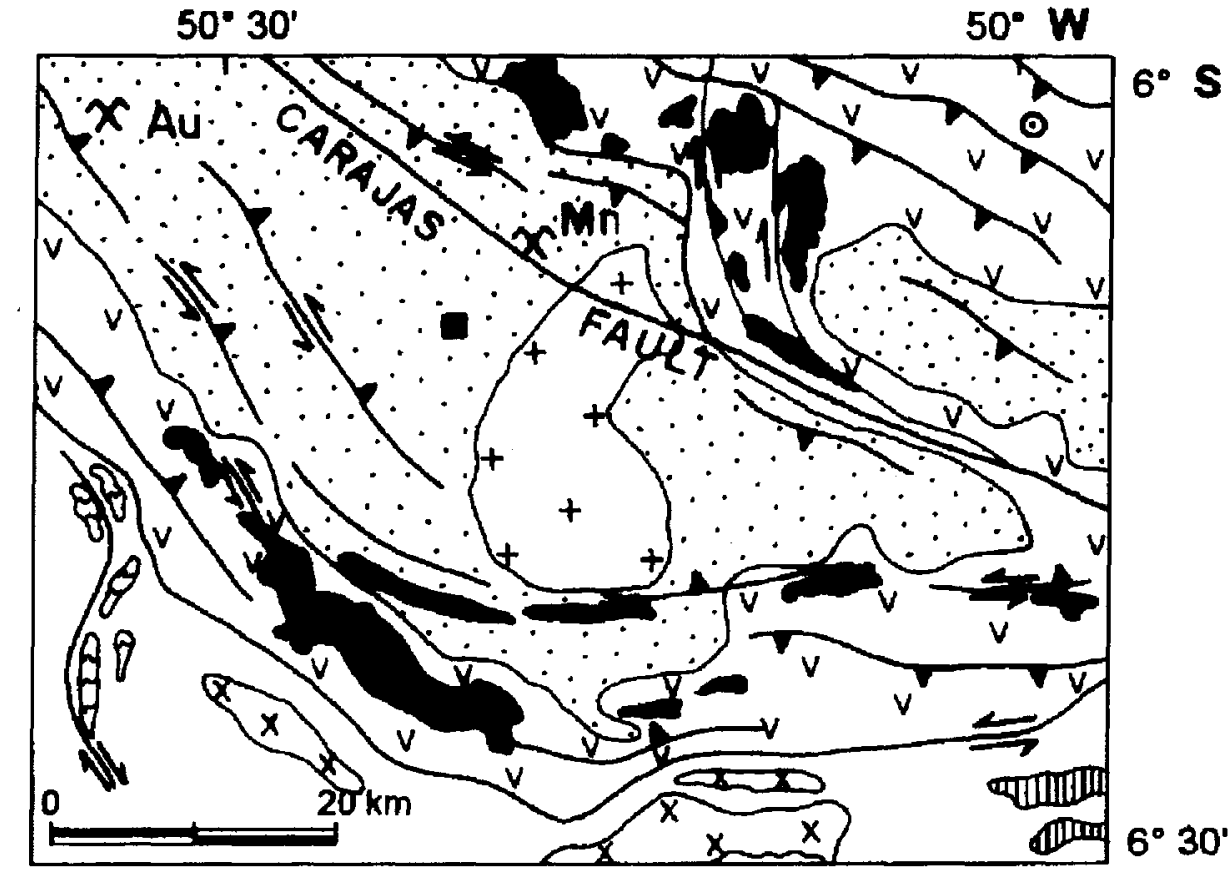

LEGEND

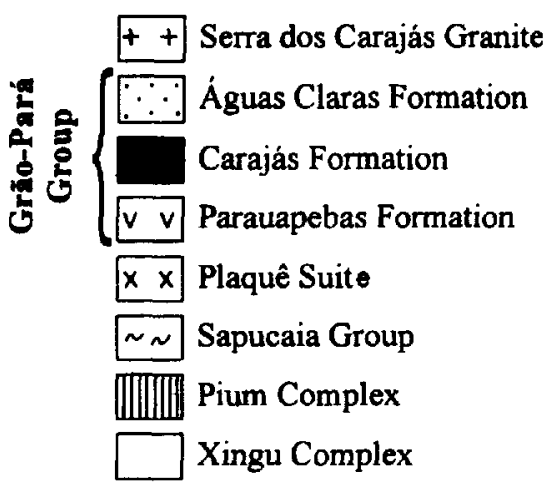

Hoblique reverse shear zone

( Thrust shear zone

W Strike-slip shear zone

$x$ Mine

- Águas Claras Deposit (ACD)

- Carajás City

Figure I - Location and geological setting of the Águas Claras deposit, Carajás (modified from Araújo et al. 1991).

roxene and plagioclase in a subophitic texture. Hornblende crystals are partially replaced by actinolite which in turn changes to chlorite and opaques. The pyroxene is almost entirely replaced by epidote whereas the plagioclase laths are so deeply transformed to sericite, epidote and albite as to render unpractical the determination of their composition. However limpid albite rims are identified in the borders of the plagioclase crystals. Some sericitized plagioclase phenocrysts developed true muscovite and are frequently cut by chlorite veinlets. Opaque primary phases occur as subhedral grains with skeletal outlines and dimensions ranging from 0.5 to 1 .Omm. Some are replaced by titanite with ilmenite lamellae exsolved from preexisting titanomagnetite.

Hydrothermal Veins and Veinlets The Águas Claras main vein zone is about $20 \mathrm{~m}$ thick and at least $400 \mathrm{~m}$ long. At depths it narrows to about $6 \mathrm{~m}$ thick at the same time that the sulfide content drops markedly and the alteration haloes are poorly developed. Individual veins and veinlets with straight to irregular borders can be observed in this zone.

Brecciation of both host rocks and veins is common. Fault planes dipping subhorizontally to subvertically show offsets in the range of $\mathrm{mm}$ to $\mathrm{cm}$ as well as slickensides oriented obliquely and perpendicularly to those planes.

The veins/veinlets are monominerallic or composed of up to five minerals. Quartz is dominant and represents the first non-metallic phase to precipitate. Chlorite and tourmaline are the most common phases associated with quartz or are related to fractures that cut the quartz veins. Regardless of the host rock, quartz and chlorite are the major phases present in the veins. Repeated fracturing/faulting allowed the quartz to (re)precipitate producing several meso- and microscopic textural arrangements (buck, comb, drusiform, phantom or spider veinlet, feather, deformation and breccia textures). Likewise distinct chlorite varieties or modes of occurrence have been observed: 1) fineto coarse-grained flakes or rosettes; 2) vermicular; 3) spheroidal; 4) subrounded to irregular concentrations filling cavities or enclosing quartz + sulfide aggregates; and 5) in veinlets (Silva 1996). Analyses of varieties 1 and 2 did not show any significant chemical difference and, according to Hey's criteria (in Deer et al. 1972), they should be classified as ripidolite.

Tourmaline is less abundant in the veins hosted by the gabbroic rocks which are also cut by veinlets composed of epidote + albite + carbonates \pm quartz \pm chlorite. Monominerallic veinlets of siderite represent a late (possibly final) stage of the Águas Claras hydrothermal system. Kaolinite occurs as filling material of cavities/pods or fracture planes open in the host rocks and quartz veins. It seems to be related to both hydrothermal and supergene processes.

The Primary Mineralization The metallic paragenesis of the Águas Claras auriferous deposit was determined from overgrowth and replacement textures displayed by ore and gangue minerals. The amounts and textural relations of the ore minerals do not vary significantly in the studied ore bodies. Body F-15 was more suitable for examination as it has better preserved sulfide associations.

In the host rocks the ore minerals occur in veinlets and less commonly as disseminations particularly in the quartz-arenites. The ore may form up to $80 \%$ of the veinlet material but in general it represents only $5-10 \%$ of its volume. Chlorite, kaolinite, tourmaline and sericite may be associated with the sulfides. Recurrent movements along fracture planes resulted in vein and host rock brecciation and their fragments have been locally cemented by pyrite. 

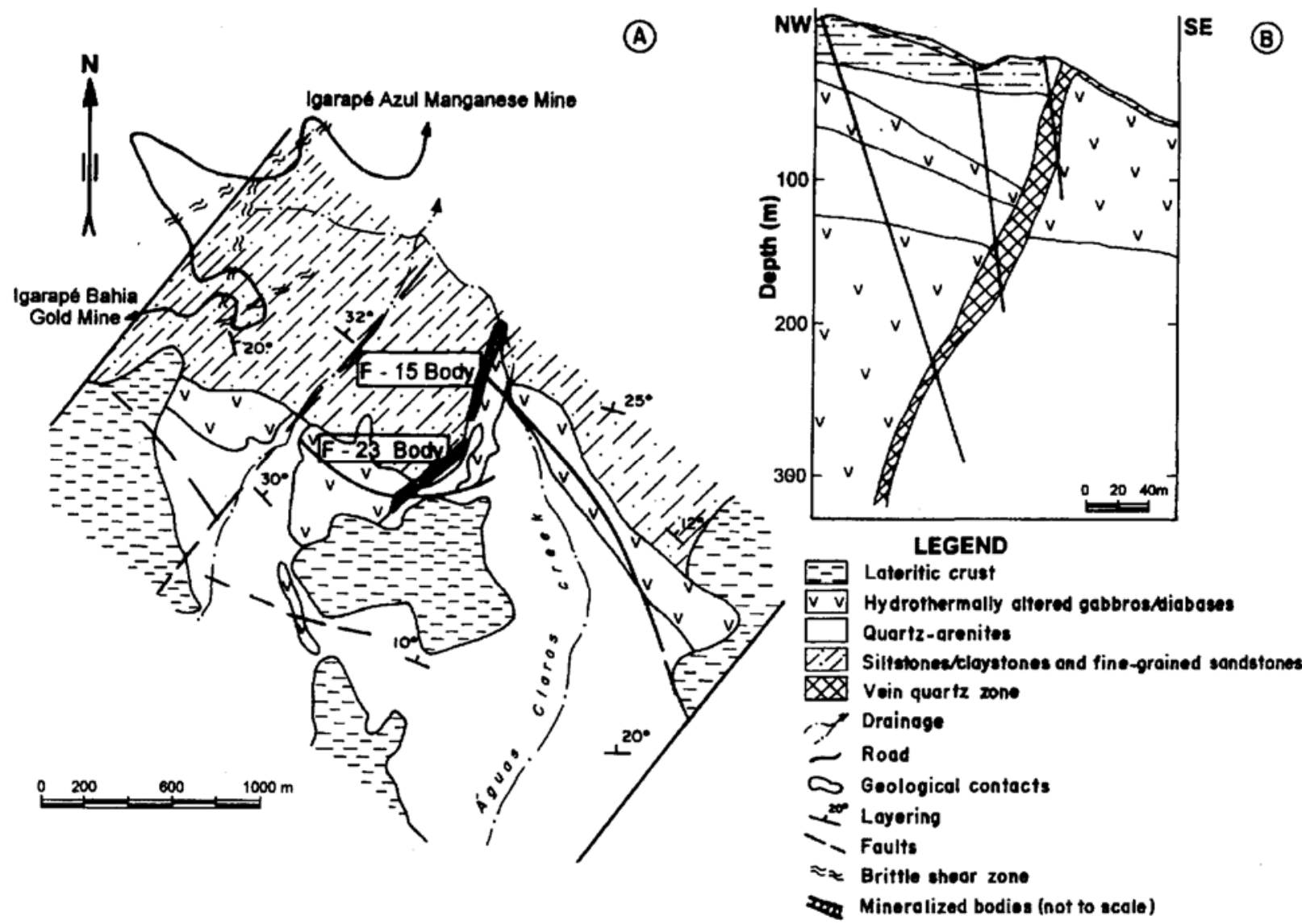

Figure 2 - A. Geologic map of the Águas Claras deposit, Carajás region. B. Schematic NW-SE vertical section of the Águas Claras vein system across the F-15 body. Modified from a Docegeo internal report.

The metallic vein paragenesis consists mainly of pyrite (20-30\%), chalcopyrite $(30-40 \%)$, sphalerite (3-8\%), arsenopyrite (3-7\%) and trace amounts of galena and pyrrhotite. Magnetite $(7 \%)$, hematite $(6 \%)$ and wolframite $(<2 \%)$ represent the oxide phases.

Chalcopyrite in the form of massive concentrations is the dominant sulfide in the veins and frequently shows lobate contacts with quartz. In general chalcopyrite replaces pyrite on fracture and cleavage planes. Inclusions of subhedral pyrite, magnetite, hematite and sphalerite are often observed in chalcopyrite masses. Another mode of occurrence of chalcopyrite is as exsolution blebs in sphalerite.

Pyrite is less abundant than chalcopyrite but locally it can be the dominant sulfide. The pyrite crystals have cubic to anhedral outlines and dimensions that range from $0.05 \mathrm{~mm}$ to $1 \mathrm{~cm}$. Sometimes they are so corroded that they have their remnants embedded in chalcopyrite indicating that pyrite was one of the earliest sulfides to precipitate. Inclusions of magnetite, hematite, sphalerite, arsenopyrite as well as local replacement by hematite are often seen in pyrite which also occurs in veinlets cutting through chalcopyrite masses.

Sphalerite occurs as inclusions in pyrite and chalcopyrite forming small (up to O.lmm in diameter) anhedral crystals either isolated or associated with iron oxides. It also occurs in veinlets cutting pyrite and chalcopyrite and as exsolution blebs in chalcopyrite.

The magnetite grains are subhedral to anhedral and have sizes in the range of 0.1 to $0.3 \mathrm{~mm}$. They are occasionally intergrown with hematite which, in turn, occurs in small grains and lamellae included or dispersed in pyrite and chalcopyrite masses.

At the borders of some quartz veinlets that transect chalcopyrite there exist euhedral arsenopyrite crystals associated with pyrite. These two sulfides also show intergrowths in which slightly blue arsenopyrite lamellae stand out particularly when pyrite grains are corroded.

Black wolframite has been classified as ferberite by X-ray diffraction analysis. It forms both irregular concentrations cut by pyrite and chalcopyrite veinlets and small apophyses intruding crystals of these two sulfides. Contacts with chalcopyrite are lobate whereas those with pyrite are poligonal. Inclusions of pyrite, chalcopyrite, hematite and quartz are commonly seen in ferberite.
Besides these phases, subordinate amounts of cobaltite, ${ }_{\mathrm{x}}$ bismuthinite, stannite and tennantite have been recorded in the Aguas Claras deposit (Soares et al. 1994).

The textural features here presented suggest a general simultaneous precipitation of all ore minerals. Pyrite, hematite and magnetite seem to have been the earliest phases formed. Chalcopirite was precipitated a little later whereas wolframite was deposited even later. However, the presence of pyrite- and wolframite-bearing veinlets transecting chalcopyrite is indicative of a reactivated hydrothermal system. $\mathrm{FeS}_{2}$ precipitation should have lasted for the entire event either as a remobilization product of preexisting pyrite or as a distinct late phase.

MODE OF GOLD OCCURRENCE Ore microscopy studies in polished sections did not detect gold particles, but microprobe analyses (Soares et al. 1994) have revealed a few fine grains with electrum composition (75\% $\mathrm{Au}$ and $25 \% \mathrm{Ag}$ ) occurring: 1) as inclusions in arsenopyrite crystals; 2) at pyrite-chalcopyrite contacts; and 3) as isolated grains in chalcopyrite aggregates. Au contents up to 40g/ton have been determined by Docegeo in samples from the gossan-rich zone which can be taken as a measure of the enrichment degree relatively to the host rocks where gold was found to be below the detection limit. The gossans consist essentially of goethite, limonite, hematite, martite, quartz, kaolinite and tourmaline.

Wall-Rock Alteration Circulation of saline aqueous solutions (see data below) along the shear zone accounted for the mineralization and the widespread hydrothermal alteration that is impressed in the host rocks of the Águas Claras deposit,

MINERALOGICAL CHANGES Chloritization, sericitization, tourmalinization, silicification, kaolinization and carbonation were the most common processes related to the mineralizing event, whereas epidotization and albitization might be associated to a previous metamorphic-hydrothermal event (Barros et al. 1994a) recorded in the area. Sericitization is the most widespread alteration type in the quartzarenites. It is present not only in the rocks near the vein system but far away from these structures as well. Sericitization did not depend on 
the presence of veinlets as the other types did. Chloritization is also ubiquitous, however it is much more intensive at the vein vicinity. Sericite- and chlorite-rich quartz-arenites are greenish gray and the higher the chlorite content the darker is the rock. Less hydrothermally altered quartz-arenites exhibit colors from pale greenish gray to white Zoning is not evident except in microscopic scale or in very few hand samples. The zones overlap each other in general and sometimes they are not simmetrically developed from the veinlets. When tourmaline is found, it is the nearest mineral to the veinlet walls followed by chlorite and sericite towards the host rocks. If the veinlet contains only chlorite, this mineral is concentrated along the veinlet borders from where it spreads throughout the host rocks transforming them partially or completely into chlorite-sandstones.

Weakly to moderately altered gabbros have a well preserved igneous texture. When more intensely altered, the original texture is severely obliterated and the evidences of brecciation and local ductile features become common. Except for plagioclase whose lath forms are still preserved despite the intense serialization, all other primary minerals are totally transformed into quartz and chlorite. Barros et ol. (1994a) proposed the existence of a metamorphic-hydrothermal event soon after the crystallization of the gabbroic rocks. During this event actinolite, chlorite, epidote, titanite, opaques, sericite and carbonates were stabilized at a temperature of $450 \pm 20^{\circ} \mathrm{C}$ at the expenses of the primary minerals. According to those authors, a second event related to the Aguas Claras minerallization caused the precipitation of abundant chlorite. However it is seldom possible to unambiguously distinguish the products of these two events.

For practical purposes, the different types of alteration will be described separately, although they usually occur in close association.

Chloritization It is the most characteristic type of alteration found in the deposit. Besides showing different optical properties, the presence of mutual intersecting chlorite veinlets suggest the existence of distinct chlorite varieties. In the quartz-arenites chlorite may reach $50 \%$ of the modal composition but a 3-20\% range is more typical. The higher the frequency of chlorite veinlets, the more abundant are the chlorite concentrations replacing pre-existing minerals in the rocks. It occurs both as fine- to medium-grained flakes and as rosettes in such a way that the chlorite seems to be a matrix of corroded quartz grains. In the gabbroic rocks, chlorite forms irregular masses that include polycrystalline quartz aggregates of hydrothermal derivation, as the alteration degree increases.

Sericitization It is much more noticeable in the quartz-arenites than in the gabbroic rocks. In the latter it is practically restricted to the plagioclase alteration, although sericite occurs in sulfide-bearing veinlets cutting the earlier chlorite veinlets. In the quartz-arenites this white mica is widespread and may represent up to $50 \%$ of the modal composition. The fine-grained mica flakes have a diffuse appearence resembling microcrystalline quartz whose presence cannot be disregarded. These flakes form a pseudo-matrix that encloses quartz grains in a typical supported grain framework. Embayments due to corrosion are characteristic of these quartz grains. Muscovite flakes can be noted in this pseudo-matrix. Some of them are detrital while others are due to hydrothermal replacement. Laminated greenish layers less than 3 $\mathrm{cm}$ thick composed of fine- to medium-grained sericite can be occasionally observed as intercalations in fine- and medium-grained quartzarenites.

The temporal relation between Chloritization and sericitization in the quartz-arenites is ambiguous. A dark green stain of chlorite-sandstone (5\% chlorite) taking over sericite-sandstone (5\% sericite) as to indicate a later formation of chlorite can be observed. On the other hand, at the contacts of these two varieties of sandstone, mutual interpenetration of both minerals suggests coprecipitation.

Tourmalinization Tourmaline is present in veinlets associated with chlorite, sulfides and less frequently with quartz and sericite. Euhedral to anhedral zoned tourmaline prisms have sizes that range from 0.1 to $0.5 \mathrm{~mm}$. Besides the existence of subhedral tourmaline remnants embedded in a chloritic mass evidences of a late Chloritization event are provided by some chloritized isolated crystals. Eventually, a random array of monominerallic tourmaline veinlets can be seen through both the chlorite-sandstone and the silicified sandstone in such a way that the rocks display a breccia-like texture.

Silicification Addition of silica to the quartz-arenites is related to the formation of quartz veinlets which gives a whitish aspect to the rocks. Near the veinlet walls there are sites with a coarser granulation due to increase in size of quartz crystals. Failure to distinguish diagenetic siliceous cement from hydrothermal silica can lead to erroneous identification of silicified sandstones.

In the gabbroic rocks, hydrothermal quartz occurs as interstitial material between primary igneous minerals. Sometimes it encloses mafic phases or forms pseudomorphs after pre-existing minerals particularly actinolite. In the more intensely altered types, the hydrothermal quartz is hard to be characterized due to its complex appearence being thereby referred to as polycrystalline aggregates. It replaces mafic phases and plagioclase generally preserving their poligonal outlines, and in turn it may be substituted for chlorite.

Argillization Kaolinite is found in the quartz-arenites both as filling material in fracture planes (hydrothermal) and in the weathering profiles (supergene). In the gabbroic rocks, the change of color to a whitish hue towards the more intensely altered types is an indication of kaolinite formation. The clay minerals could not be precisely identified but were inferred from the occurrence of brownish turbid fine-grained aggregates. Clay minerals and chlorite locally define a S-C -like foliation in these rocks.

Carbonation Carbonate minerals are much more frequently observed in the gabbroic rocks where they occur as disseminations and monominerallic veinlets. The closer to the minerallized zone, the more abundant they are. Replacement of mafic phases and plagioclase along cleavage planes is common, while in veinlets the carbonates are found as spherulites or rhomboedral crystals. X-ray diffratometric analysis allowed the identification of both calcite and siderite, the latter being particularly abundant in the later veinlets that cut earlier ones.

Epidotization Epidote formation is essentially restricted to the gabbroic rocks and, according to most evidences, is related to the propylitic alteration that occurred previously to the mineralizing event. Epidote crystals vary from 0.2 to $0.8 \mathrm{~mm}$ in size and from anhedral to euhedral forms. They replace plagioclase, pyroxene and actinolite grains partially or completely. Another mode of occurrence is in veinlets associated with albite, chlorite, carbonates and quartz.

Albitization Albite/sodic oligoclase is found both in the basic rocks and in monominerallic veinlets associated or not with epidote. In the former the albitization results from the plagioclase decalcification and is easily recognized at the crystal borders as limpid albite rims showing polysinthetic twinning, although they may occasionally be sericitized/chloritized.

CHEMICAL CHANGES Chemical analyses have been performed in twenty samples of quartz-arenites and gabbros representative of the main alteration types described above. The selection, based on petrographic data, excluded those rocks intensely silicified or rich in quartz-veinlets. Trace elements were especially chosen according to the ore mineral associations.

Sedimentary Sequence The main processes that acted upon the sedimentary rocks were sericitization, Chloritization and tourmalinization. Tables 1 and 2 present the mineral associations of the samples analysed and the corresponding chemical composition ordered according to decreasing silica contents.

Sulfide-free quartz-arenites with preserved diagenetic features and less than $5 \%$ of hydrothermal minerals were considered to be virtually unaltered. Sample 1 was taken as the most representative of these unaltered arenites since it has the highest silica content $(97.1 \%)$ and the lowest value for loss on ignition $(0.62 \%)$. In addition, the sum of alkalis is $0.45 \%$ while the contents of $\mathrm{A}_{2} \mathrm{O}_{3}$ and $\mathrm{FeO}_{\mathrm{t}}+\mathrm{MgO}$ are 1.6 and $<0.47 \%$ respectively. All these values are consistent with the extremely low degree of alteration of that sample.

Sample 1 plus samples 2 to 5 presenting silica values between 94.3 and $96.9 \%$ make up the group of the least altered quartz-arenites. Although they have a fairly homogeneous chemical composition they differ from each other in that a distinct hydrothermal mineral is dominant. Moreover, the lower the silica content the higher is the alteration degree. Indeed, this can be easily observed when all eleven quartz-arenite samples are plotted in comparison to sample 1 (Fig. 3).

A better insight of the progressive increase of the alteration degree is given by multielemental diagrams (Fig. 4). The less altered quartzarenites show a homogeneous behavior for all major elements. Increase in the alteration degree leads to decreases in silica content and increases in other components. Sericitization is characterized by the addition of $\mathrm{K}_{2} \mathrm{O}$ and $\mathrm{Al}_{2} \mathrm{O}_{3}$, while Chloritization is marked by the enrichment in $\mathrm{MgO}$ and $\mathrm{FeO}_{\mathrm{t}}$. Samples 10 and 11 are those most sericitized and chloritized respectively. The silica contents of these two samples are as much as half of that of sample 1 what gives a measure of the intensity 
of the quartz grain dissolution due to the hydrothermal processes. High alumina and low total iron concentrations also correspond to the more serialized samples. Conversely, samples rich in chlorite and tourmaline have lower alumina and higher total iron concentrations.

The distribution of trace elements in the slightly to intensely altered quartz-arenites is also shown in figure 4 . The high B contents (480 $4,100 \mathrm{ppm}$ ) typify the tourmalinized rocks with peaks well above the average $(30 \mathrm{ppm})$ determined for the other samples. The average $\mathrm{Cu}$ and $\mathrm{Zn}$ concentrations in the slightly to moderately altered quartzarenites (samples 1 Jo 8 ) are respectively 28 and $35 \mathrm{ppm}$, but $\mathrm{Zn}$ contents increase significantly in the chloritized (sample 11) and tourmalinized (sample 9) arenites averaging $116 \mathrm{ppm}$. The latter also show fairly high $\mathrm{Cu}$ concentration $(412 \mathrm{ppm})$. The highest $\mathrm{Pb}$ and $\mathrm{Co}$ contents $(59 \mathrm{ppm})$ are found in the chloritized arenite and correspond to about 2 or 3 times the average values ( 27 and $20 \mathrm{ppm}$ respectively) for all samples. As contents are rather low but become significant in the sericitized $(60 \mathrm{ppm})$ and chloritized $(31 \mathrm{ppm})$ arenite. They are relatively high also in sample 2 whose fractured nature might have allowed a more intense flow of mineralizing solutions. Sn distribution displays only one peak above the $5 \mathrm{ppm}$ background and corresponds to the tourmalinized arenite $(64 \mathrm{ppm})$. W has an erratic behavior with the highest and lowest values found respectively in the less altered arenites $(84 \mathrm{ppm})$ and in the chlorite-rich rocks $(<15 \mathrm{ppm})$. The W average of $48 \mathrm{ppm}$ is much higher than the 2 to $4 \mathrm{ppm}$ range published for sandstones (Wedepohl 1976), probably, indicating a selective hydrothermal influx of this metal into the Águas Claras unit or even original anomalous contents in these rocks. $\mathrm{Bi}$ and $\mathrm{Sb}$ were found to be below the detection limit.

Metabasic Hypabyssal Rocks The rock samples selected for chemical analyses were those with the major abundance of hydrothermal minerals. Their modal compositions (Table 3 ) were only roughly estimated by visual means owing to the fine granulation and complex texture of the rocks. The chemical results (Table 4) refer to nine samples of gabbro/diabase ordered according to decreasing $\mathrm{SiO}_{2}$ content.

Less transformed gabbros (LTG) have been divided by Barros et al. (1994a) into four subtypes based on the modal amounts of clinopyroxene $(\mathrm{Cpx}>30 \% ; 30>\mathrm{Cpx}>15 \% ; 15>\mathrm{Cpx}>4 \%$; and $\mathrm{Cpx}<4 \%)$. In order to appraise relative gains and losses of components in the hydrothermalized gabbros (Fig. 5), comparisons are done below with reference to the average chemical composition of the LTG.

Sample 104 has the chemical composition that best compares to the LTG despite having somewhat lower contents of $\mathrm{SiO}_{2}, \mathrm{CaO}$ and $\mathrm{Na}_{2} \mathrm{O}$, and somewhat higher contents of $\mathrm{FeO}_{\mathrm{t}}$ and $\mathrm{LOI}$. In the more intensely altered samples $\mathrm{Na}_{2} \mathrm{O}$ and $\mathrm{CaO}$ have been almost completely leached out accompanying the destruction of plagioclase and actinolite at the same time that $\mathrm{H}_{2} \mathrm{O}$ has been added and $\mathrm{SiO}_{2}$ lost. As a consequence, large amounts of chlorite, sericite and clay minerals have been formed withholding $\mathrm{Fe}, \mathrm{Mg}$ and $\mathrm{K}$ in the rocks.

The strongly chloritized samples (138 and 24) show lower concentrations of $\mathrm{SiO}_{2}$, alkalies and lime, but $\mathrm{FeO}_{\mathrm{t}}$ and $\mathrm{MgO}$ concentrations are higher. No significant difference is noted for $\mathrm{TiO}_{2}$ and $\mathrm{Al}_{2} \mathrm{O}_{3}$ contents. Sample 139 is intensely chloritized as well but is also silicified with quartz occurring either as large poligonal crystals of unknown origin (late magmatic? hydrothermal?) or as polycrystalline aggregates. This sample is unusually rich in $\mathrm{TiO}_{2}(2.2 \%)$ probably as a result of a previous anomalous concentration of Ti-rich primary phases that have been presently stabilized as titanite.

Samples 12,107,142 and 142A with varied proportions of sericite, clay minerals and chlorite present lower contents of $\mathrm{SiO}_{2}, \mathrm{CaO}$ and $\mathrm{Na}_{2} \mathrm{O}$, and higher contents of $\mathrm{Al}_{2} \mathrm{O}_{3}$ and LOI. In particular, the strongly kaolinized sample $142 \mathrm{~A}$ has one of the highest contents of $\mathrm{Al}_{2} \mathrm{O}_{3}$ $(21.7 \%)$ and LOI $(8.29 \%)$. FeO $\mathrm{t}_{\mathrm{t}}$ is higher in all but one sample (107). $\mathrm{MgO}$ and $\mathrm{FeO}_{\mathrm{t}}$ are normally higher whereas $\mathrm{TiO}_{2}$ is pratically the same. Just one sample has a much lower concentration of $\mathrm{K}_{2} \mathrm{O}$; the remaining components show no meaningful differences due to the ubiquitous presence of sericite that has certainly prevented this oxide from being removed from the rocks. In fact, it is credited to the formation of sheet silicates the overall relative $\mathrm{Al}_{2} \mathrm{O}_{3}$ enrichment and $\mathrm{SiO}_{2}$ impoverishment in those samples.

Sample 106 stands out amongst all samples since it records the highest values for $\mathrm{Al}_{2} \mathrm{O}_{3}(22.1 \%), \mathrm{K}_{2} \mathrm{O}(1.8 \%)$ and LOI $(10.34 \%)$ in conformity with its strong altered character. It has also the highest $\mathrm{Fe}_{2} \mathrm{O}_{3}$ value (Silva 1996). Despite the partial preservation of igneous texture, this sample shows a foliation marked by the pod-like arrangement of chlorite, sericite and clay minerals under the microscope.
As far as the trace element distribution is concerned (Fig. 5), there is no correlation with the alteration types already described. B shows low concentrations (average of $14.5 \mathrm{ppm}$ ) except in samples 24 (88ppm) and $104(1280 \mathrm{ppm})$ where tourmaline is present. W and $\mathrm{Sn}$ have a fairly homogeneous distribution with average contents of 30 and $16 \mathrm{ppm}$ respectively. $\mathrm{Bi}$ and $\mathrm{Sb}$ were found to be below the detection limit. As shows a wide variation with most samples falling in the 1 to 3ppm range and only two being richer: 24 (12ppm) and 104 (48ppm). Cu, Pb, Zn and Co contents are highly variable and, despite the lack of correlation with the alteration types, $\mathrm{Cu}$ and $\mathrm{Co}$ tend to be higher in the sericite- and chlorite-rich samples while $\mathrm{Zn}$ tends to be richer in those containing clay minerals and sericite. In short, comparatively to the LTG, these metals have similar or higher contents in the altered gabbros reaching in particular $4.1 \% \mathrm{Cu}$ (sample 106) and $704 \mathrm{ppm} \mathrm{Zn}$ (sample 142). There is no way out other than concluding that these trace elements were transported by hydrothermal fluids and mostly discharged as the rocks became more and more altered.

HYDROTHERMAL FLUIDS A fluid inclusion study was undertaken aiming at defining the composition and physical conditions of the fluids at the Águas Claras mineralization site. Several doubly polished wafers of vein quartz with buck, phantom veinlet and comb textures were prepared for microthermometric analyses with a Chaixmeca freezing-heating stage.

Inclusion shapes vary from sharp negative crystals to irregular forms and sizes range from $<2$ to 20 urn. Their distribution and occurrence favor a primary origin with no evidences of leakage or necking-down. Most inclusions have a degree of filling estimated at 0.9 and daughter minerals have similar dimensions.

Based on phase numbers they display at room temperature four types of aqueous inclusions have been recognized (Silva 1996): 1) liquid-vapor-solid (LVS); 2) liquid-vapor (LV); 3) liquid-solid (LS); and 4) liquid (L). No safe criteria were found to define the chronological relationships among them and microthermometric analyses were performed only in types 1 and 2 due to the metastable behavior of the other two types.

Eutectic temperatures $\left(\mathrm{T}_{\mathrm{e}}\right)$ for both LV and LVS types show a distinct peak in the $-62 /-54^{\circ} \mathrm{C}$ range indicating that the fluids can be ascribed to the $\mathrm{NaCl}-\mathrm{CaCl}_{2}-\mathrm{H}_{2} \mathrm{O}$ ternary system. Other cations like $\mathrm{Mg}^{+2}$ and $\mathrm{Fe}^{+2}$ should be present to account for temperatures lower than $-52^{\circ} \mathrm{C}$ which is the $\mathrm{T}_{\mathrm{e}}$ for the system above mentioned (Shepherd et al. 1985). Similar fluid compositions have been found in the Carajás deposits of Igarapé Pojuca (Medeiros Neto \& Villas 1985; Winter 1994) and Igarapé Bahia (Ribeiro \& Villas 1990) as well as in veins present in the Serra dos Carajás granite (Rios et al. 1995). All these fluids should have been driven through the abundant Archean basic rocks present in the region from which those elements have been largely scavenged.

Hydrohalite melting temperatures in the LV inclusions varied from -41.7 to $-18.6^{\circ} \mathrm{C}$ with the highest frequency ( $42 \%$ of the measurements) in the $-20 /-25^{\circ} \mathrm{C}$ range. In the LVS inclusions the occurrence of metastability produced unrealistic values of 5 to $12^{\circ} \mathrm{C}$ for the hydrohalite melting temperatures. The confidence degree for the hydrohalite identification was high, although the presence of other hydrates cannot be completely ruled out.

Ice melting temperatures $\left(\mathrm{Tm}_{\mathrm{icc}}\right)$ in the $\mathrm{LV}$ inclusions occurred between -30 and $-0.3^{\circ} \mathrm{C}$ displaying a highly skewed distribution pattern. Fifty four percent of measurements were in the -5 to $-0.3^{\circ} \mathrm{C}$ range. The Bodnar equation (Goldstein \& Reynolds 1994) yielded salinities of 0.53 to $>23.50$ wt. $\% \mathrm{NaCl}$ equiv. with major frequency in the range of 0.53 to 7.86 wt. $\% \mathrm{NaCl}$ equiv. Calculated densities vary from 0.9 to $1.1 \mathrm{~g} / \mathrm{cm}^{3}$. Tm $\mathrm{Tm}_{\text {ice }}$ of the LVS inclusions were from -30.5 to $-25.6^{\circ} \mathrm{C}$.

During the heating procedure, the $\mathrm{LV}$ inclusions homogenized into the liquid phase between 102 to $387^{\circ} \mathrm{C}$. The most frequent values $(40 \%)$ were in the $160-190^{\circ} \mathrm{C}$ range. This was considered as the minimum trapping temperatures for these fluids. In the LVS inclusions, the liquid phase homogenized prior to the halite dissolution, between $150-200^{\circ} \mathrm{C}$. The total homogenization occurred between $185-360^{\circ} \mathrm{C}$. The estimated salinities correspond to $30-45 \mathrm{wt} . \% \mathrm{NaCl}$ equiv. according to the equation proposed by Sterner et al. (1988).

DISCUSSION AND INTERPRETATION The discussion will be focused on three main aspects of the ACD: 1) the vein system;2) the evolution of the mineralizing fluids; and 3) the hydrothermal alteration and the primary mineralization.

The Vein System The ACD is a vein-type deposit spatially related to a NE-SW trending shear zone with apparent sinistrai movement and brittle to brittle-ductile nature. Quartz-arenites and gabbroic 
rocks were not only tectonically placed in contact to each other but also subjected to an intense circulation of mineralizing aqueous solutions that flowed along the shear zone. The sulfide ore is disseminated to massive but stockwork and brecciated patterns can be locally found. The mineralization is doubtlessly related to the development of the shear zone. However, detailed studies on the geometric and temporal relationships of the shear zone with the rock units present in the ACD and in the surrounding areas, as well as with the regional structura discontinuities necessary to truly understand the tectonic conditions under which the mineralization took place are still lacking.

The shear zone presents an essentially brittle behavior with associated breccias and comminution features. However, a more brittle-ductile behavior is indicated by both an incipient foliation of the gabbroic rocks and mechanical twinning of the vein quartz. On the other hand, due to their more competent character, the quartz-arenites have behaved in a more brittle way than the gabbroic rocks.

The nature of a hydrothermal system and the structural conditions not only control but also bring about the textural types of vein quartz. Being the most common mineral in veins, the quartz characteristics might reflect the prevailing physical conditions during vein formation. Quartz with comb, drusiform and feather textures is found in low pressure environments, whereas that with buck, fanthom veinlet and breccia textures are more typical of greater depths (Adams 1920; Dowling \& Morrinson 1989). All these kinds of quartz textures are

Table 1 - Hydrothermal mineral associations of Aguas Claras quartzarenite samples for which chemical analyses were performed in this study.

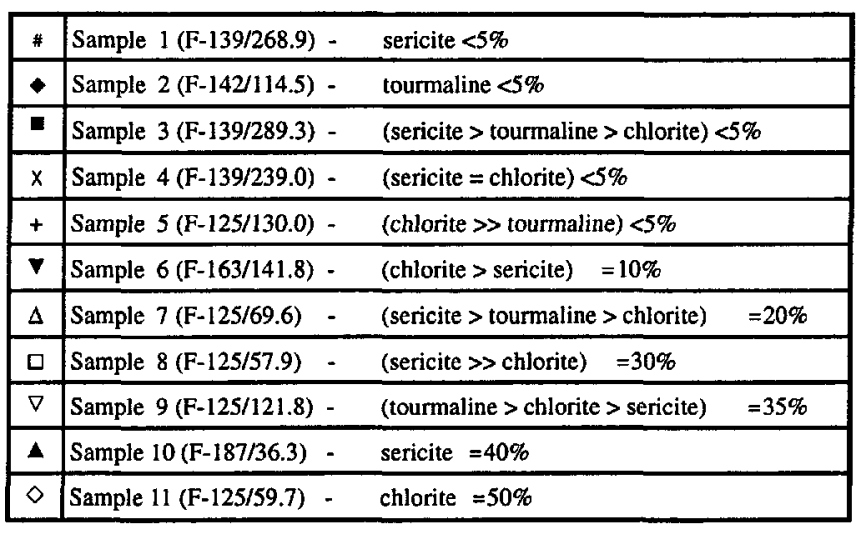

present in the ACD vein system, although the low pressure types seem to be dominant.

Common fragments of altered and unaltered host rock as well as sheared and non-sheared quartz vein indicate repeated fracturing and episodic fluid flow into the ACD ore formation environment. Several quartz generations can be the result of multiple hydrothermal events rather than seismic activity along a host structure (Dowling \& Morrinson 1989). An opposed point of view advocates that the mechanism of vein formation is highly dependent on the dynamic effects associated with earthquake faulting (Sibson 1987; Sibson et al 1988). Similar mechanisms may have occurred in the development of the ACD system. The successive hydrothermal pulses could be also related to highly pressurized fluids that might have induced hydraulic fracturing of the veins and host rocks as evidenced by the presence of very angular and non-oriented fragments in the ACD breccias.

The mutual cross-cut relationships between quartz, chlorite and tourmaline veinlets/veins also suggest episodic crack-and-seal processes for the formation of the Aguas Claras vein which Led to the replacement of earlier hydrothermal minerals by later ones as in the chloritization of tourmaline.

The Evolution of the Mineralizing Fluids In order to understand the evolution of the fluids responsible for the ACD mineralization, it is important to refer to the four major geological events that have been recorded in the area. Although the temporal relationships

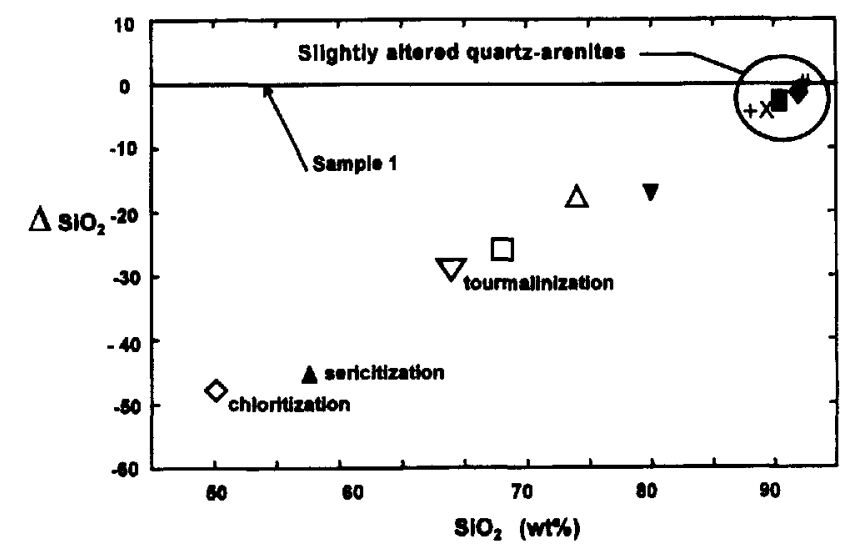

Figure 3 - Diagram depicting the alteration degree of quartz arenites based on silica contents. Full line represents the least altered (sample 1) to which all other samples are referred. Symbols as in table 1. $\Delta$ siO2 $=\left(\mathrm{SiO}_{2}-97.1\right) \%$

Table 2 - Chemical composition of the Águas Claras quartz-arenite samples from table l, Carajás region. Major elements (wt. \%) and trace elements (ppm). LOI = loss on ignition.

\begin{tabular}{|c|c|c|c|c|c|c|c|c|c|c|c|}
\hline & 1 & 2 & 3 & 4 & 5 & 6 & 7 & 8 & 9 & 10 & 11 \\
\hline $\mathrm{SiO}_{2}$ & 97.10 & 96.90 & 95.20 & 94.80 & 94.30 & 84.50 & 78.50 & 72.40 & 68.60 & 56.90 & 49.90 \\
\hline $\mathrm{TiO}_{2}$ & $<0.05$ & $<0.05$ & $<0.05$ & $<0.05$ & $<0.05$ & 0.19 & 0.18 & 0.33 & 0.14 & 0.66 & 0.32 \\
\hline $\mathrm{Al}_{2} \mathbf{0}_{3}$ & 1.60 & 1.60 & 2.30 & 2.50 & 1.80 & 6.20 & 10.60 & 16.30 & 9.90 & 26.80 & 13.20 \\
\hline $\mathrm{FeO}_{\mathrm{t}}$ & $<0.37$ & 0.71 & 1.38 & 1.23 & 2.33 & 3.45 & 4.54 & 2.55 & 11.98 & 1.68 & 18.01 \\
\hline $\mathrm{MnO}$ & $<0.01$ & $<0,01$ & 0.01 & 0.01 & 0.04 & 0.01 & 0.07 & 0.03 & 0.27 & $<0.01$ & 0.15 \\
\hline MgO & $<0.10$ & $<0.10$ & $<0.10$ & 0.39 & 0.56 & 2.10 & 1.00 & 0.68 & 2.70 & 0.70 & 10.00 \\
\hline $\mathrm{CaO}$ & $<0.05$ & $<0.05$ & $<0.05$ & $<0.05$ & 0.05 & $<0.05$ & $<0.05$ & $<0.05$ & 0.08 & $<0.05$ & $<0.05$ \\
\hline $\mathrm{Na}_{2} \mathrm{O}$ & 0.02 & 0.06 & 0.03 & 0,02 & 0.02 & 0.03 & 0.11 & 0.09 & 0.21 & 0.12 & 0.02 \\
\hline $\mathrm{K}_{2} \mathrm{O}$ & 0.43 & 0.03 & 0.40 & 0.48 & 0.05 & 1.10 & $2.30)$ & 4.90 & 0.45 & 8.30 & 0.16 \\
\hline $\mathbf{P}_{2} \mathbf{O}_{5}$ & $<0.05$ & $<0.05$ & $<0.05$ & $<0.05$ & $<0.05$ & $<0.05$ & $<0.05$ & $<0.05$ & $<0.05$ & $<0.05$ & $<0.05$ \\
\hline & 0.02 & 0.03 & 0.02 & 0.02 & 0.02 & 0.04 & 0.06 & 0.08 & 0.10 & 0.14 & 0.19 \\
\hline LOI & 0.26 & 0.45 & 0.43 & 0.54 & 0.62 & 1.73 & 1.93 & 2.48 & 2.59 & 3.98 & 6.05 \\
\hline $\mathrm{O}=\mathrm{F}$ & $<0.01$ & -0.01 & $<0.01$ & $<0.01$ & $<0.01$ & -0.02 & -0.03 & -0.03 & -0.04 & -0.06 & -0.08 \\
\hline TOTAL & 99.71 & 99.82 & 99.86 & 100.06 & 99.86 & 99.48 & 99.42 & 99.88 & 97.50 & 99.36 & 98.41 \\
\hline B & 50 & 900 & 480 & 32 & 37 & $<10$ & 890 & 53 & 4100 & 19 & 14 \\
\hline $\begin{array}{l}W \\
S n\end{array}$ & $\begin{array}{l}84 \\
<5\end{array}$ & $\begin{array}{l}69 \\
<5\end{array}$ & 36 & 42 & 75 & 40 & 22 & 27 & 58 & 24 & $<15$ \\
\hline $\begin{array}{l}\text { Sn } \\
\mathrm{Cu}\end{array}$ & $\begin{array}{l}<3 \\
17\end{array}$ & $\begin{array}{l}<5 \\
67\end{array}$ & $\begin{array}{l}<5 \\
14\end{array}$ & $\begin{array}{l}<5 \\
52\end{array}$ & $\begin{array}{l}<5 \\
11\end{array}$ & $\begin{array}{r}<5 \\
8\end{array}$ & $\begin{array}{l}<5 \\
35\end{array}$ & $\begin{array}{l}<5 \\
79\end{array}$ & $\begin{array}{r}64 \\
412\end{array}$ & $\begin{array}{l}<5 \\
94\end{array}$ & $<5$ \\
\hline $\mathbf{P b}$ & $<5$ & $<5$ & $<5$ & 5 & 5 & 8 & 8 & 5 & $\begin{array}{r}412 \\
19\end{array}$ & $\begin{array}{l}74 \\
10\end{array}$ & $\begin{array}{l}43 \\
59\end{array}$ \\
\hline $\mathrm{Zn}$ & 12 & 12 & 17 & 15 & 31 & 27 & 54 & 54 & 174 & 21 & 158 \\
\hline Co & 11 & 42 & 8 & 6 & 12 & 15 & 20 & 23 & 33 & 24 & 59 \\
\hline $\mathbf{N i}$ & $<25$ & $<25$ & $<25$ & $<25$ & $<25$ & $<25$ & $<25$ & $<25$ & $<25$ & $<25$ & 47 \\
\hline $\mathrm{Cr}$ & 27 & $<20$ & 82 & $<20$ & 27 & 89 & 82 & 103 & 27 & 171 & 123 \\
\hline Bi & $<10$ & $<10$ & $<10$ & $<10$ & $<10$ & $<10$ & $<10$ & $<10$ & $<10$ & $<10$ & $<10$ \\
\hline As & 2 & 47 & 1 & 1 & 1 & I & 4 & 9 & 2 & 60 & 31 \\
\hline $\mathbf{S b}$ & 1 & 1 & I & $<1$ & $<1$ & $<1$ & $<1$ & $<1$ & I & $<1$ & $<1$ \\
\hline
\end{tabular}


between the last two events are still uncertain, a tentative chronological order might be 1) deposition of the Águas Claras sediments; 2) emplacement of gabbroic sills and dikes; 3 ) intrusion of the Serra dos Carajás granite (SCO); and 4) development of the shear zone and formation of the Águas Claras sulfide \pm Au deposit.

A time break of ca. $0.8 \mathrm{Ga}$ in the stratigraphic record separates the deposition of the Águas Claras Formation (minimum age of $2.64 \mathrm{Ga}$ Dias et al. 1996) and the emplacement of the SCG batholith (1.88 Ga; Machado et al. 1991). The Carajás fault represents the main structural descontinuity mapped in the region, but its age and temporal relationships with the SCG batholith are still unknown. Similarly, insufficient structural data allow only speculative links between the Carajás fault and the shear zone that has controlled the ACD mineralization.

The genetic relationship between the mineralization and the Serra dos Carajás granite has not been proved yet, although recent $\mathrm{Sm}-\mathrm{Nd}$ and $\mathrm{Pb}-\mathrm{Pb}$ isotopic results favor a link with this intrusion (Mougeot $e t$ al 1996b). If this interpretation is correct, the mineralizing event would be related to the Proterozoic distensive tectonics and the granite would be an important source for the hydróthermal solutions as well as for the thermal energy necessary to their circulation.

Fluid inclusion studies on both barren and mineralized vein quartz indicate that the aqueous solutions generally have high salinities (up to 45 wt. $\% \mathrm{NaCl}$ equiv.) and consist mainly of $\mathrm{Na}+, \mathrm{Ca}^{+2}, \mathrm{Mg}+{ }^{2}$ and $\mathrm{Cl}-$, corresponding to the $\mathrm{NaCl}-\mathrm{CaCl}_{2}-\mathrm{H}_{2} \mathrm{O}$ or $\mathrm{NaCl}-\mathrm{CaCl}_{2}-\mathrm{MgCl}_{2}-$ $\mathrm{H}_{2} \mathrm{O}$ systems. Despite the assumption of recurrent hydróthermal episodes, the sources and migration paths of the fluids should have been essentially the same.

The three-phase inclusions present high temperatures $\left(330-360^{\circ} \mathrm{C}\right)$ and salinities (30-45\% wt. \% $\mathrm{NaCl}$ equiv.), but they also show a lower

Table 3 - Estimated modal composition (\% vol.) and simplified description of the Águas Claras altered gabbroic rocks, Carajás region. MZ $=$ mineralized zone

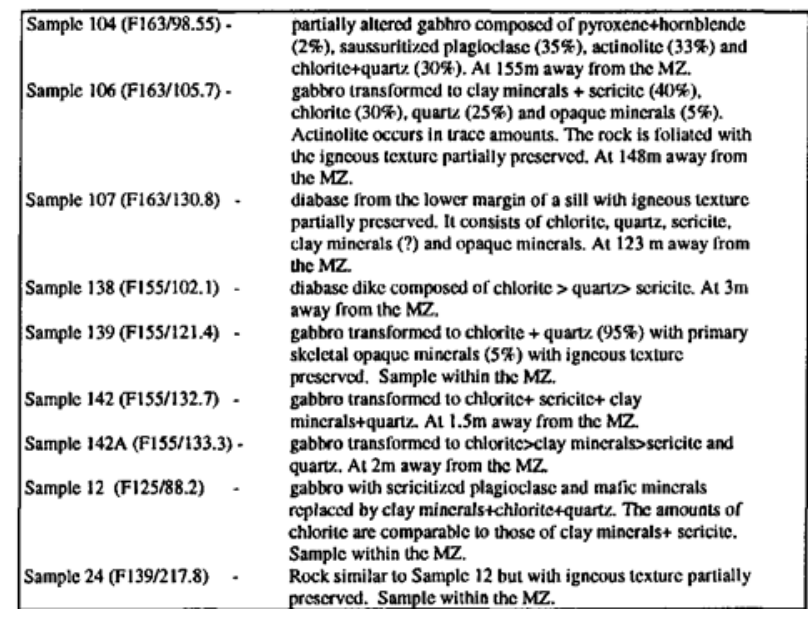

thermal range $\left(185-260^{\circ} \mathrm{C}\right)$. In turn, the two-phase inclusions have the $160-190^{\circ} \mathrm{C}$ thermal range as the most representative fluid trapping minimum temperatures and salinities that vary from 0.53 to $>23.5$ wt.\% $\mathrm{NaCl}$ equiv. Despite the overlap around $200^{\circ} \mathrm{C}$, there is an evident temperature decrease following the formation of the two- and threephase inclusions. Similarly, there is a salinity decrease, but close to $200^{\circ} \mathrm{C}$ the salinity variation becomes erratic so that low to moderate saline two-phase inclusions are found beside each other. All these data suggest mixing of higher temperature brines with cooler and less saline fluids probably of meteoric origin.

As the temperature decreased, the fluids became poorer in $\mathrm{Ca}, \mathrm{Na}$, $\mathrm{K}, \mathrm{Fe}, \mathrm{Mg}, \mathrm{Al}, \mathrm{Si}$ and $\mathrm{B}$ owing to the precipitation of chlorite, sericite, tourmaline, clay-minerals, epidote(?) and albite(?). Occasionally, in response to the vein fracturing, renewed solution flows have caused episodic salinity increases at the same time that the system as a whole had its thermal energy dissipated.

High $\mathrm{Na}$ and $\mathrm{Ca}$ concentrations have certainly resulted from the leaching of the gabbroic rocks during the hydróthermal alteration. These rocks have played an important role as main source of other elements such as $\mathrm{Mg}, \mathrm{Fe}$ and $\mathrm{Al}$ that were partially removed from the solutions through the precipitation of chlorite which is the most characteristic alteration mineral of the ACD. In addition to all those cations, the solutions have also transported $\mathrm{W}, \mathrm{Cu}, \mathrm{Zn}, \mathrm{Co}, \mathrm{Pb}$ and $\mathrm{Au}$ as indicated by the presence of specific minerals and chemical analyses of the ore material and altered rocks.

The occurrence of wolframite and cassiterite as minor hydróthermal minerals in the ACD system may corroborate the genetic link with a granitic magmatism. However, the influence of de SCG batholith as a fluid source is debatable since its specialization in these elements has not yet been proved. Cassiterite concentrations in the Águas Claras sediments near the SCG western border indicate the existence of Sn source in the region that is yet to be unraveled. This source could be hidden granitic bodies at depth or eroded away, or even more evolved and specialized facies distinct from those so far described (Barros et al. 1994b;Rioseffl/. 1995).

Hydróthermal Alteration and Primary Mineralization The ACD host rocks have undergone an intense and varied hydróthermal alteration caused by the interaction with the mineralizing fluids which accounted for both the formation of quartz vein system and the precipitation of gold and sulfides. Away from the mineralized zone, these rocks bear evidences of having been altered by a previous hydróthermal event responsible for the widespread serieitization of the quartz-arenites and the propilitization of the gabbroic rocks.

Petrographic and chemical data show that the quartz-arenites have undergone chloritization, serialization, tourmalinization and silica losses as the main alteration processes (Tab. 5). Chlorite and tourmaline formation is intimately related to the mineralization since they always occur in or near the veins and veinlets. Sericite, on the other hand, may be a product of diagenesis as well as a hydróthermal mineral as suggested by its two distinct modes of occurrence. Accordingly, the fine-grained and the coarse-grained varieties could represent respectively an earlier diagenetic generation and a later one directly related to the mineralizing event.

Table 4 - Chemical composition of the Águas Claras gabbroic rocks, Carajás region. Major elements (wt. \%) and trace elements (ppm). Sample identification follows table 3. LOI=loss on ignition; Cpx=clinopyroxene; - = not determined; * wt. \%

\begin{tabular}{|c|c|c|c|c|c|c|c|c|c|c|c|c|c|}
\hline & Cpro30\% & $30>$ Cpxo15\% & $15>\mathrm{C} p>>4 \%$ & Cpx<4\% & \begin{tabular}{|l}
139 \\
\end{tabular} & 24 & 107 & 12 & 142 & 138 & 104 & 106 & $142 A$ \\
\hline $\mathrm{SiO}_{2}$ & 49.15 & 49.59 & 48.73 & 48.53 & 51.40 & 47.90 & 47.90 & 45.50 & 44.000 & 43.90 & 42.50 & 38.70 & 37.20 \\
\hline $\mathrm{TiO}_{2}$ & 0.61 & 0.83 & 1.15 & 1.09 & 2.20 & 0.69 & 1.10 & 0.97 & 0.82 & 1.00 & 0.61 & 1.10 & 1.10 \\
\hline $\mathrm{Al}_{2} \mathbf{O}_{3}$ & 15.30 & 14.47 & 14.26 & 15.14 & 11.50 & 14.20 & 16.40 & 16,80 & 15.60 & 14.79 & 16.20 & 22.10 & 21.70 \\
\hline & 9.94 & 13.0 & 14.33 & 14.57 & 19.04 & 17.60 & 13.88 & 18.82 & 20.89 & 19.42 & 17.55 & 13.09 & 19.64 \\
\hline MnO & 0.17 & 0.22 & 0.23 & 0.22 & 0.11 & 0.16 & 0.10 & 0.28 & 0.76 & 0.19 & 0.28 & 0.08 & 0.70 \\
\hline $\mathrm{MgO}$ & 6.98 & 7.71 & 5.64 & 5.51 & 7.60 & 9.80 & (0.9) & 7.60 & 6.80 & 11.30 & 7.20 & 4.80 & 7.20 \\
\hline $\mathrm{CaO}$ & 11.71 & 9.42 & 9.0 & 8.9 & 0.28 & $<0.05$ & 0.05 & $<0.05$ & 0.05 & 0.17 & 6.10 & 0.68 & 0.05 \\
\hline $\mathrm{Na}_{2} \mathrm{O}$ & 2.12 & 2.64 & 2.45 & 2.78 & 0.01 & 0.15 & 0.01 & 0.02 & 0.02 & $<0.01$ & 1.40 & 0.03 & 0.02 \\
\hline $\mathrm{K}_{2} \mathrm{O}$ & 1.61 & 1.13 & 1.18 & 0.55 & 0.01 & 0.06 & 0.20 & 1.50 & 1.70 & 0.17 & 0.12 & 1.80 & 1.20 \\
\hline $\mathrm{P}_{2} \mathrm{O}_{5}$ & 0.16 & 0.18 & 0.2 & 0.21 & 0.15 & $<0.05$ & $<0.05$ & $<0.05$ & $<0.05$ & $<0.05$ & $<0.05$ & 0.05 & 0.12 \\
\hline $\mathbf{F}$ & - & - & - & - & 0.10 & 0.18 & $<0.09$ & 0.09 & 0.11 & 0.12 & 0.11 & 0.05 & 0.11 \\
\hline LOI & 1.60 & 1.76 & 1.83 & 2.07 & 5.27 & 6.49 & 7.43 & 5.94 & 6.51 & 6.87 & 5.19 & 10.34 & 8.29 \\
\hline$O=F$ & - & . & - & . & -0.04 & $-0,08$ & -0.04 & -0.04 & -0.05 & -0.05 & 0.05 & -0.02 & -0.05 \\
\hline TOTAL & 99.58 & 101.27 & 99.41 & 100.02 & 98.09 & 97.74 & 98.85 & 98.15 & 97.83 & 98.40 & 97.56 & 94.11 & 97.84 \\
\hline B & $\cdot$ & - & $\cdot$ & $\cdot$ & 18 & 88 & $<10$ & $<10$ & 18 & 11 & 1280 & 14 & 18 \\
\hline w & - & - & - & . & $<15$ & $<15$ & 32 & 26 & 64 & 19 & $<15$ & $<15$ & 66 \\
\hline Sn & - & - & - & - & $<5$ & 24 & $<5$ & 33 & $<5$ & $<5$ & 52 & $<5$ & $<5$ \\
\hline $\mathrm{Cu}$ & 148 & 75 & 73 & 99 & 2805 & 1541 & 1463 & 14 & 159 & 16 & 29 & $4.1^{*}$ & 81 \\
\hline $\mathrm{Pb}$ & - & - & - & - & 26 & 25 & 23 & 25 & 36 & 25 & 20 & 19 & 32 \\
\hline $\mathrm{Zn}_{\mathbf{n}}$ & 104 & 139 & 135 & 207 & 73 & 95 & 111 & 575 & 704 & 306 & 152 & 523 & 502 \\
\hline Co & 81 & 94 & 99 & 104 & 51 & 246 & 78 & 92 & 113 & 61 & 123 & 270 & 109 \\
\hline $\mathrm{Ni}$ & 124 & 96 & 99 & 110 & $<25$ & 87 & 102 & 102 & 87 & 71 & 79 & 370 & 102 \\
\hline $\mathrm{Cr}$ & 415 & 101 & 140 & 109 & 82 & 246 & 315 & 308 & 472 & 294 & 246 & 315 & 356 \\
\hline $\mathbf{B i}$ & $\cdot$ & . & $\cdot$ & $\cdot$ & $<10$ & $<10$ & $<10$ & $<10$ & $<10$ & $<10$ & $<10$ & $<10$ & $<10$ \\
\hline As & - & . & - & - & 2 & 12 & 1 & 1 & 2 & 1 & 48 & 3 & 3 \\
\hline Sb & - & . & - & - & 1 & 1 & I & 1 & 1 & 1 & 1 & 1 & 1 \\
\hline
\end{tabular}


The chronology between sericite and chlorite is hard to be defined on the basis of the available information inasmuch as they occur either as intergrowth flakes or show mutual replacement relationships. In the first case both minerals would be contemporaneous products of the mineralizing event, whereas in the other case ambiguous textural features would not allow saying which one has been lastly formed. Furthermore, a coexisting greenish mica with high interference colors (phengite?) may apparently be a replacement product of either minerals what makes the paragenesis even more difficult to be interpreted.

Evidences of silica losses are plenty. Besides the decreasing silica contents as the hvdrothermal minerals became more and more abun- dant, desequilibrium features represented by both corroded detrital grains and the intense replacement of the siliceous cement point out to the relatively high chemical reactivity of the otherwise non-reactive quartz-arenites under the prevailing physico-chemical conditions of the ACD system. The solution $\mathrm{pH}$ should have been neutral to alkaline to account for the silica leaching (in the $200-300^{\circ} \mathrm{C}$ range neutral $\mathrm{pH}$ varies from 5.5 to 5.7 ). Indeed, the supply of $\mathrm{K}^{+}, \mathrm{Mg}^{2}, \mathrm{Fe}^{+2}, \mathrm{Al}^{+3}$, etc, aqueous species from the alteration of the enclosing rocks, particularly those of gabbroic composition, should have been accompanied by a $\mathrm{pH}$ decrease. At the same time, those cations had been transferred to the solutions that could have then interacted with the auartz-arenites.
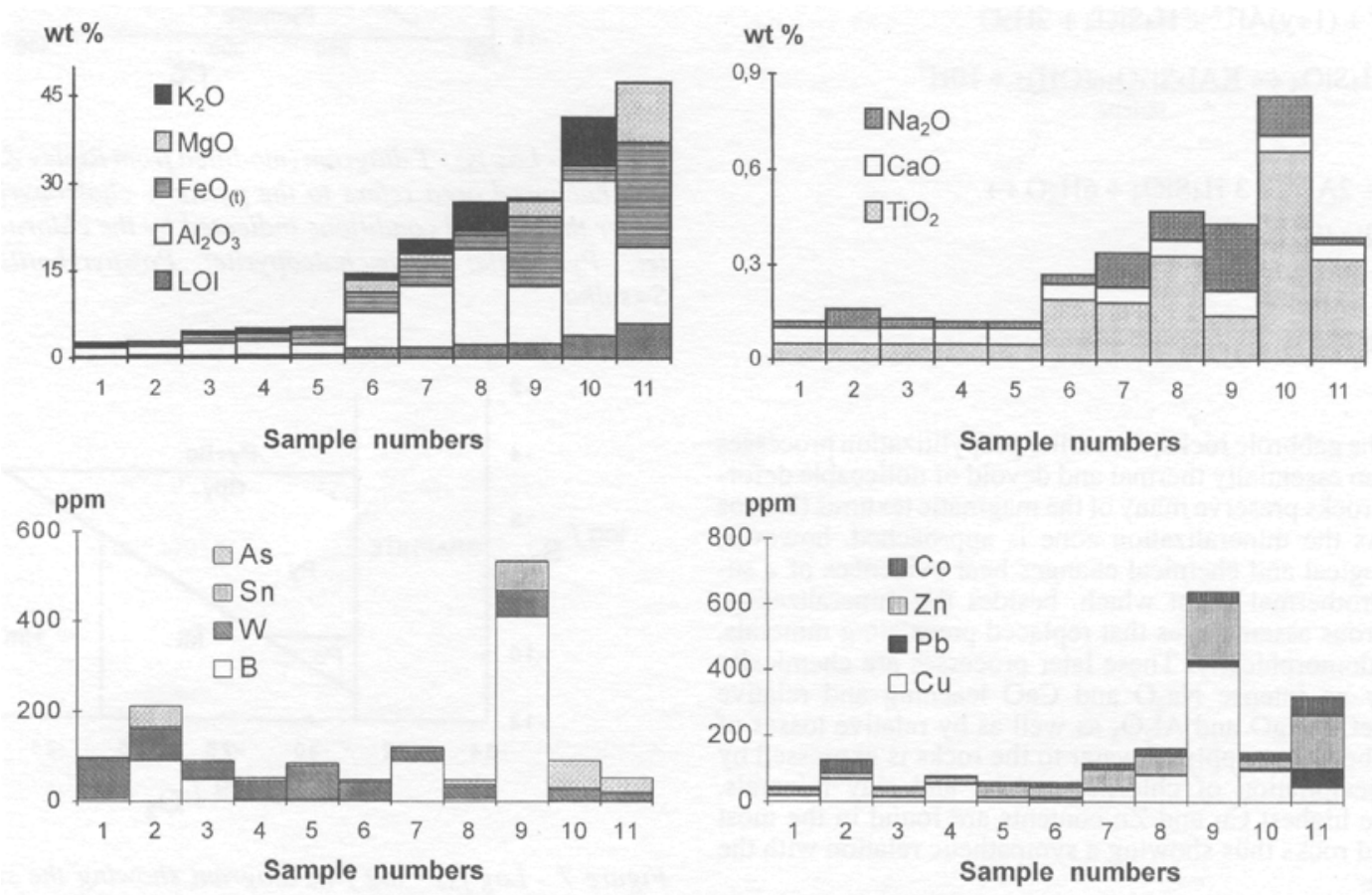

Figure 4 - Diagram showing the content distribution of major components (wt.\%) and trace elements (ppm) in quartz-arenites from virtually unaltered (samples I to 5) to intensely altered rocks (samples 9 to 11). Samples 6 to 8 represent moderately altered rocks whose chemical behavior is greatly controlled by their dominant hydrothermal minerals. Sample identification follows table 1.

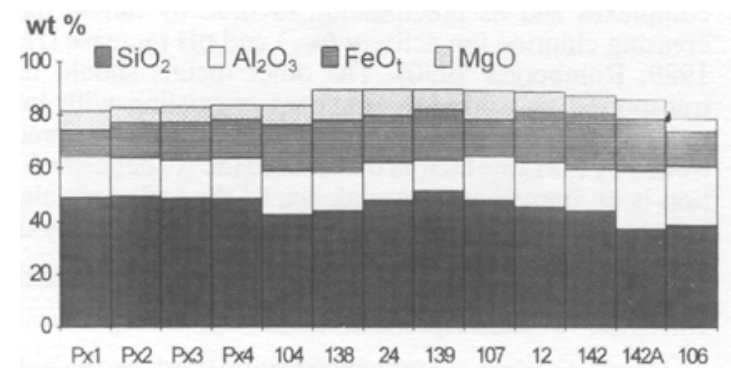

Sample numbers

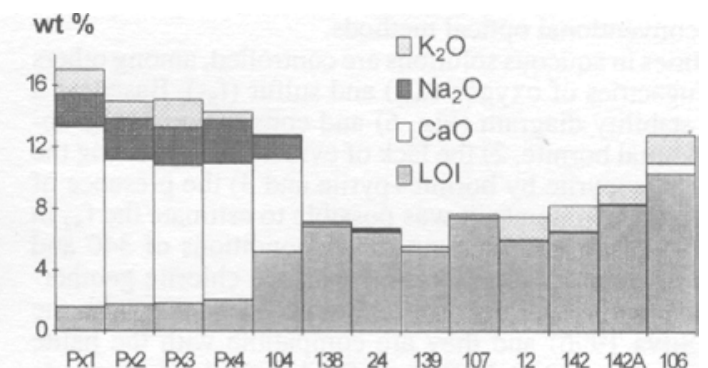

Sample numbers

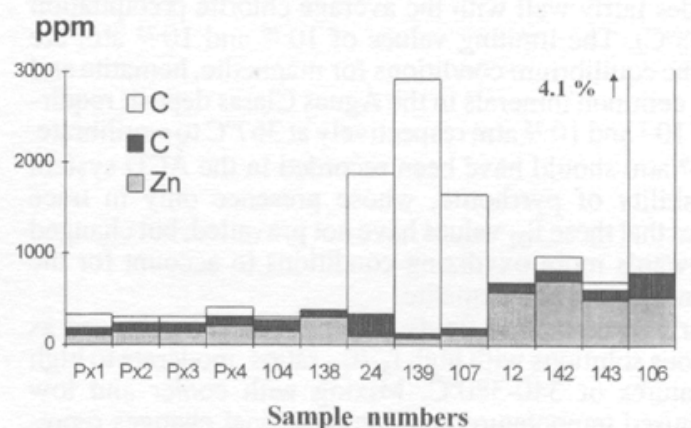

Figure 5 - Cumulative distribution of major components (wt. \%) and trace elements (ppm) in Águas Claras altered gabbroic rocks comparatively to the less altered ones. Sample numbers follow table 3. Pxl to Px4=clinopyroxene gabbro: (1) Cpx>30\%; (2) 30>Cpx>15\%; (3) $15>C p x>4 \%$; (4) $C p x<4 \%$. 
However, the sericite and chlorite precipitation implies production of $\mathrm{H}^{+}$ions so that the system as a whole may have been chemically buffered around a neutral $\mathrm{pH}$. The reactions below describe a possible way for the $\mathrm{H}^{+}$ion balance

$$
\begin{aligned}
& \mathrm{CaAl}_{2} \mathrm{Si}_{2} \mathrm{O}_{8}+\mathrm{NaAlSi}_{3} \mathrm{O}_{8}+12 \mathrm{H}^{+}+4 \mathrm{H}_{2} \mathrm{O} \leftrightarrow \mathrm{Ca}^{+2}+\mathrm{Na}^{+}+ \\
& \text {plagioclase } \\
& 3 \mathrm{Al}^{+3}+5 \mathrm{H}_{4} \mathrm{SiO}_{4}
\end{aligned}
$$

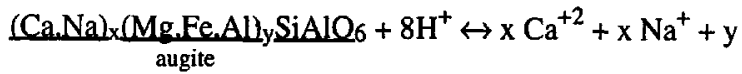

$$
\begin{aligned}
& \mathrm{y} \mathrm{Mg}^{+2}+\mathrm{y} \mathrm{Fe}^{+2}+(1+\mathrm{y}) \mathrm{Al}^{+3}+\mathrm{H}_{4} \mathrm{SiO}_{4}+2 \mathrm{H}_{2} \mathrm{O} \\
& \left.\mathrm{K}^{+}+3 \mathrm{Al}^{+3}+3 \mathrm{H}_{4} \mathrm{SiO}_{4} \leftrightarrow \mathrm{KAl}_{3} \mathrm{Si}_{3} \mathrm{O}_{10} \mathrm{OOH}\right)_{2}+10 \mathrm{H}^{+} \\
& \text {sericite }
\end{aligned}
$$

$$
\begin{aligned}
& 3 \mathrm{Mg}^{+2}+2 \mathrm{Fe}^{+2}+2 \mathrm{Al}^{+3}+3 \mathrm{H}_{4} \mathrm{SiO}_{4}+6 \mathrm{H}_{2} \mathrm{O} \leftrightarrow \\
& \underset{\text { chlorite }}{\mathrm{Mg}_{3} \mathrm{Fe}_{2} \mathrm{Al}_{2} \mathrm{Si}_{3} \mathrm{O}_{10} \mathrm{OOH} \mathrm{O}_{8}+16 \mathrm{H}^{+}}
\end{aligned}
$$

$$
\frac{\mathrm{SiO}_{2}}{\text { quartz }}+\mathrm{H}_{2} \mathrm{O} \leftrightarrow \mathrm{H}_{4} \mathrm{SiO}_{4}
$$

Concerning the gabbroic rocks, the earlier propylitization processes seem to have been essentially thermal and devoid of noticeable deformation since the rocks preserve many of the magmatic textures (Barros et al. 1994a). As the mineralization zone is approached, however, distinct mineralogical and chemical changes bear evidences of a superimposed hydrothermal event which, besides the mineralization, gave rise to hydrous assemblages that replaced preexisting minerals, sometimes pseudomorphically. These later processes are chemically characterized by an intense $\mathrm{Na}_{2} \mathrm{O}$ and $\mathrm{CaO}$ leaching and relative enrichment of $\mathrm{FeO}_{\mathrm{t}}, \mathrm{MgO}$ and $\mathrm{Al}_{2} \mathrm{O}_{3}$ as well as by relative losses of $\mathrm{SiO}_{2}$ (Tab. 5). The large supply of water to the rocks is expressed by the abundant precipitation of chlorite, sericite and clay minerals. Significantly, the highest $\mathrm{Cu}$ and $\mathrm{Zn}$ contents are found in the most hydrothermalized rocks thus showing a sympathetic relation with the alteration degree.

The ACD ore association is dominated by $\mathrm{Fe}$ and $\mathrm{Cu}$ sulfides with subordinate amounts of $\mathrm{Zn}$ and W. According to Soares et al. (1994), the presence of tennantite and cobaltite associated with chalcopyrite and arsenopyrite defines the $\mathrm{Fe}-\mathrm{Cu}-\mathrm{Co}-\mathrm{As}-\mathrm{S}$ system as an adequate one for the ore minerals. Supergene enrichment apart, Au has been not detected by the conventional optical methods.

Metal solubilities in aqueous solutions are controlled, among others factors, by the fugacities of oxygen $\left(\mathrm{f}_{\mathrm{O} 2}\right)$ and sulfur $\left(\mathrm{f}_{\mathrm{S} 2}\right)$. Based on a temperature- $f_{\mathrm{S}_{2}}$ stability diagram (Fig. 6) and considering 1 ) the absence of hydrothermal bornite, 2) the lack of evidences supporting the replacement of chalcopyrite by bornite+pyrite and 3) the presence of pyrrhotite only in trace amounts, it was possible to estimate the $f_{\mathrm{S}_{2}}$ in the range of $\mathrm{KM}$ to $10^{-9}$ atm for temperature conditions of 340 and $380^{\circ} \mathrm{C}$. These temperatures were obtained with the chlorite geothermometer using compositional data for a chlorite coexisting with the ACD sulfides (Silva 1996) and they are compatible with the halite dissolution temperatures $\left(330-360^{\circ} \mathrm{C}\right)$ of fluid inclusions in quartz crystals also contemporaneous with the sulfides. The corresponding $\mathrm{f}_{02}$ were estimated from a $\mathrm{f}_{\mathrm{S} 2}-\mathrm{fo} 2$ diagram constructed at $367^{\circ} \mathrm{C}$ (Fig. 7) which coincides fairly well with the average chlorite precipitation temperature $\left(358^{\circ} \mathrm{C}\right)$. The limiting values of $10^{-29}$ and $10^{-23} \mathrm{~atm}$ are consistent with the equilibrium conditions/or magnetite, hematite and pyrite which are common minerals in the Aguas Claras deposit requiring $\mathrm{f}_{\mathrm{S} 2}$ and $\mathrm{f}_{02}$ of $10^{7}$ and $10^{-25}$ atm respectively at $367^{\circ} \mathrm{C}$ to equilibrate. Initial $\mathrm{f}_{02}<1 \mathrm{O}^{29}$ atm should have been recorded in the ACD system to allow the stability of pyrrhotite, whose presence only in trace amounts indicates that these $\mathrm{f}_{02}$ values have not prevailed, but changed progressively towards more oxydizing conditions to account for the precipitation of magnetite and hematite.

The ACD early mineralizing fluids may be then characterized as very saline aqueous solutions with high $\mathrm{f}_{\mathrm{S} 2} / \mathrm{f}_{\mathrm{O} 2}$ ratios, moderate to high $\mathrm{f}_{02}$ and temperatures of $340-380^{\circ} \mathrm{C}$. Mixing with cooler and low salinity fluids caused temperature and compositional changes represented by the LV inclusions.

Most likely the $\mathrm{pH}$ was initially acid to allow the $\mathrm{H}^{+}$metasomatism of the rock minerals with which the solutions have interacted as it is clearly evidenced by the argillization of the gabbroic rocks. Under such

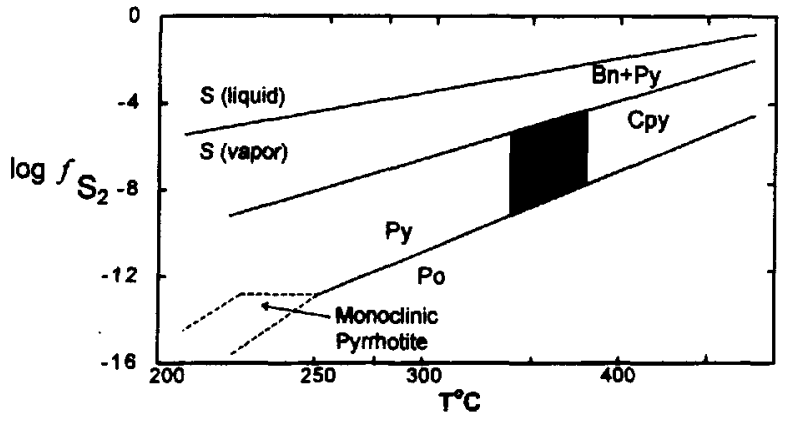

Figure 6 - Log f32 - T diagram (modifiedfrom Ripley \& Ohmoto 1977). The hachured area refers to the pyrite + chalcopyrite precipitation under the thermal conditions indicated by the chlorite geothermometer. Py=pyrite; $C p y=$ chalcopyrite; Po=pyrrhotite; $B n=$ bornite; $S=$ sulfur

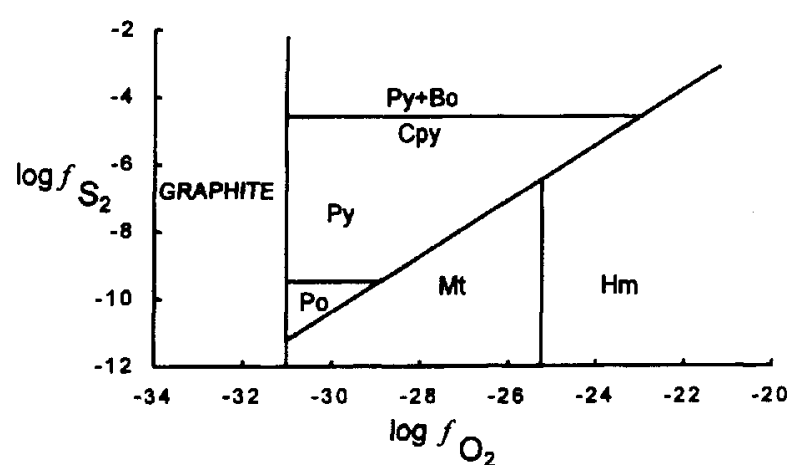

Figure $7-\log f_{s} 2-\log f 02$ diagram showing the stability fields of pyrrhotite (Po), pyrite (Py), bornite (Bn), magnetite (Mt) and hematite (Hm) at $367^{\circ} \mathrm{C}$ (modified from Gilmer et al. J988).

conditions, Au could have been essentially transported as chloride complexes and its precipitation favored by falling temperature, decreasing chlorine ion activity (ac,.) and $\mathrm{pH}$ increase (Huston \& Large 1989; Romberger 1990). The other metals should have also been transported as chloride complexes coexisting with low amounts of reduced sulfur species, particularly $\mathrm{H}_{2} \mathrm{~S}$, and their precipitation controlled by the same factors that caused the Au deposition. $\mathrm{H}+$ consumption is an immediate consequence of the wall rock alteration and its influence on the $\mathrm{Au}$ precipitation can be described by the reaction

$4 \mathrm{AuCl}_{2}^{-}+2 \mathrm{H}_{2} \mathrm{O} \leftrightarrow \rightarrow 4 \mathrm{Au}_{\mathrm{s}}+4 \mathrm{H}^{+}+8 \mathrm{Cl}^{-}+\mathrm{O}_{2}$ (Henley 1973)

where the "s" subscript means solid.

However, more recent experimental work on the gold solubility in the range of $350-450^{\circ} \mathrm{C}$ (Gilbert et al. 1993) has shown that the $\mathrm{Au}$ transport as AuClf is negligible, but neutral thio-complexes like $\mathrm{AuHS}^{\circ}$ or $\mathrm{HAu}(\mathrm{HS})_{2}{ }^{\circ}$ are dominant as transporting agents in acid to neutral solutions. Typical reactions could be

$$
\mathrm{Au}_{\mathrm{s}}+2 \mathrm{H}_{2} \mathrm{~S} \leftarrow \rightarrow \mathrm{HAu}(\mathrm{HS})_{2}{ }^{\circ}+1 / 2 \mathrm{H}_{2(\mathrm{~g})}
$$

Wolframite (ferberite) is cogenetic with the $\mathrm{Fe}-\mathrm{Cu}$ sulfides and Fe-oxides and was probably preferentially formed under $\mathrm{fc}_{2}$ conditions compatible with the magnetite-hematite buffer. Its precipitation could be described by the following reactions

$$
\begin{aligned}
& \mathrm{Au}_{\mathrm{s}}+\mathrm{H}_{2} \mathrm{~S} \leftarrow \rightarrow \mathrm{AuHS}^{\circ}+1 / 2 \mathrm{H}_{2(\mathrm{~g})} \\
& \mathrm{FeCl}^{-}+\mathrm{HWO}_{4}{ }^{-} \leftarrow \rightarrow \mathrm{FeWO}_{4}+\mathrm{H}^{+}+\mathrm{Cl}^{-\prime}
\end{aligned}
$$

$$
\mathrm{H}_{2} \mathrm{WO}_{4}{ }^{\circ}+\mathrm{FeCl}_{2}{ }^{\circ} \leftarrow \rightarrow \mathrm{FeWO}_{4}+2 \mathrm{HCl}^{\circ} \text { (Henrich 1990) }
$$

and therefore is favored by the activity decreases of $\mathrm{H}^{+}, \mathrm{Q}$ - and $\mathrm{HC}^{\circ}$. The latter could be accomplished by simple dilution due to fluid mixing. 
Table 5 - Qualitative mass transfer evaluation in the ACD resulting from the hydrothermal processes associated with the mineralization

\begin{tabular}{|c|c|c|c|c|}
\hline ROCK TYPES & $\begin{array}{l}\text { HIDROTERMAL } \\
\text { PROCESSES }\end{array}$ & $\begin{array}{l}\text { REDISTRIBUTED } \\
\text { COMPONENTS }\end{array}$ & $\begin{array}{c}\text { ADDED } \\
\text { COMPONENTS }\end{array}$ & $\begin{array}{l}\text { LEACHED } \\
\text { COMPONENTS }\end{array}$ \\
\hline $\begin{array}{l}\text { Diabases/ } \\
\text { Gabbros }\end{array}$ & $\begin{array}{l}\text { Chloritization, sericiti- } \\
\text { zation, argillization, } \\
\text { silicification } \pm \text { tourma- } \\
\text { linization } \pm \text { carbona- } \\
\text { tion. }\end{array}$ & $\begin{array}{l}\mathrm{Al}_{2} \mathrm{O}_{3}, \mathrm{FeO}_{1}, \mathrm{MgO}, \\
\mathrm{K}_{2} \mathrm{O}, \mathrm{SiO}_{2}\end{array}$ & $\begin{array}{l}\mathrm{Al}_{2} \mathrm{O}_{3}, \mathrm{H}_{2} \mathrm{O}, \mathrm{B} \\
\mathrm{Cu}, \mathrm{Zn}, \mathrm{Co}, \mathrm{CO}_{2}, \\
\mathrm{~S}\end{array}$ & $\mathrm{CaO}, \mathrm{Na}_{2} \mathrm{O}, \mathrm{SiO}_{2}$ \\
\hline $\begin{array}{l}\text { Quartz- } \\
\text { arenites }\end{array}$ & $\begin{array}{l}\text { Chloritization, sericiti- } \\
\text { zation, tourmalin iza- } \\
\text { tion } \pm \text { argillization. }\end{array}$ & & $\begin{array}{l}\mathrm{Al}_{2} \mathrm{O}_{3}, \mathrm{FeO}_{4}, \mathrm{MgO} \\
\mathrm{K} 2 \mathrm{O}, \mathrm{H}_{2} \mathrm{O}, \mathrm{B}, \mathrm{Cu}, \\
\mathrm{Zn}, \mathrm{As}, \mathrm{W}, \mathrm{Sn}, \mathrm{S}\end{array}$ & $\mathrm{SiO}_{2}$ \\
\hline
\end{tabular}

CONCLUSIONS The Águas Claras mineralization consists of $\mathrm{Fe}-\mathrm{Cu}$ sulfides $\pm \mathrm{Au}$ hosted by a quartz-vein that has been deposited along a brittle to brittle-ductile sub-vertical NE-SW trending shear zone. This structure transects Archean gabbroic sills and dikes intrusive into the Águas Claras Formation.

Chloritization is the dominant hydrothermal alteration type, but sericitization, tourmalinization, silicification, argillization and carbonation are also important. Their intensities are highly variable particularly if the nature of the country rocks is considered. Epidotization and albitization also occur but they are more typical of the gabbroic rocks and are most likely related to an earlier propilitization event.

The vein quartz shows comb, phantom, massive, feather and brecciated textures that reflect the physical conditions of deposition. Accordingly, the first two are indicative of low pressure, near surface environments, whereas the others have been developed at greater depths.

The hydrothermal alteration related to the mineralizing event is characterized in the quartz-arenites by addition of $\mathrm{FeO}_{\mathrm{t}}, \mathrm{MgO}, \mathrm{K}_{2} \mathrm{O}$, $\mathrm{Al}_{2} \mathrm{O}_{3}, \mathrm{TiO}_{2}, \mathrm{~B}$ and $\mathrm{H}_{2} \mathrm{O}$, and removal of $\mathrm{SiO}_{2}$. In the gabbros, the alteration is mainly represented by the intense leaching of $\mathrm{Na}_{2} \mathrm{O}$ and $\mathrm{CaO}$, and $\mathrm{H}_{2} \mathrm{O}$ supply.

The gabbroic rocks have had an important role in the overall chemical equilibrium of the ACD system, since they have acted as suppliers of $\mathrm{Na}, \mathrm{Ca}, \mathrm{Mg}, \mathrm{Fe}$ and $\mathrm{Al}$ to the mineralizing solutions. $\mathrm{Cu}$, $\mathrm{Zn}, \mathrm{Co}, \mathrm{Pb}$ and $\mathrm{Au}$ could have had as sources not only the volcanicsedimentary sequences that make up the regional basement but also the host gabbroic rocks themselves.
Chalcopyrite, pyrite, magnetite, hematite, sphalerite and ferberite represent the main ore association. Gold, although not observed in the primary mineralization in this study, takes part of the paragenesis associated with arsenopyrite and chalcopyrite (Soares et al 1994). Supergene transformations of the chalcopyrite to bornite, chalcocite, covellite and native copper are common and have been generated at varying depths. These transformations are also responsible for the $\mathrm{Au}$ enrichment to economic values.

Relatively oxydizing conditions have prevailed during the sulfide precipitation as can be deduced from the pyrite-magnetite-hematite equilibrium assemblage. Estimates of the $\mathrm{f}_{\mathrm{S}_{2}}$ and $\mathrm{f}_{\mathrm{O} 2}$ provide ranges of $10^{19}-\mathrm{KM}$ atm and $\mathrm{IO}^{29}-10^{23}$ atm respectively. Microthermometric data on quartz vein pointed out to a stage dominated by aqueous brines with compositions corresponding to the $\mathrm{NaCl}-\mathrm{CaCl}_{2}-\mathrm{MgCl}_{2}-\mathrm{H}_{2} \mathrm{O}$ system. Temperatures based on the halite dissolution were found to be $185-360^{\circ} \mathrm{C}$ which are partially coincident with those provided by the chlorite geothermometer $\left(340-380^{\circ} \mathrm{C}\right)$. This higher thermal range is interpreted to represent the initial temperatures for the vein formation. Similar data on the LV inclusions revealed greater temperature (150 $\left.-390^{\circ} \mathrm{C}\right)$ and salinity $(0.53->23.50 \mathrm{wt} \% \mathrm{NaCl}$ equiv. $)$ variations which may suggest a mineral deposition resulting from cyclic events. However, the low salinity, low temperature fluids shall represent later solutions in the ACD evolution or even mixing with meteoric waters.

The ACD is structurally controlled and formed at shallow depths. The low pressure environment is compatible with the fluid inclusion data, vein-filling textures and low metamorphic grade of the country rocks. Regarding the vein system, textural characteristics bear evidences that it was formed by episodic hydrothermal solution pulses responsible for several quartz and sulfide generations, as well as for fluids of different salinities.

Acknowledgments Thanks are due to Docegeo mining company geologists for their logistic support and permission to use maps, cross-sections and drill-hole core samples for this study. CMOS is indebted both to the Geochemistry and Petrology Department and Graduate Program in Geology and Geochemistry of the Federal University of Pará for their support to the accomplishment of this research. The present paper was much improved with the criticism and comments of two anonimous RGB reviewers. Their contribution is greatly appreciated.

\section{References}

ADAMS, S.F. 1920. A microscopic study of vein quartz. Econ. Geoi, 15: 623-664 ANAISSE JR, J. 1995. Petrografia dos arenitos da Formação Águas Claras, Pré-cambriano, Serra dos Carajás. In: SEMANA DE INICIAÇÃO CIENTÍFICA DA UFPA, 12, Belém, 1995. Poster session.

ARAÚJO, O.J.B.; MAIA, R.G.N.; JOÃO, X.S.J.; COSTA, J.B.S. 1988. A megaestruturação arqueana da folha Carajás. In: SIMP. LATINO AMERICANO GEOL., 7, Belém, 1988. Proceedings... Belém, v. 1, p. 324-333

ARAÚJO, O.J.B.; MAIA, R.G.N.; JOÃO, X.S.J.; COSTA, J.B.S. 1991. Trabalhos anteriores e contexto geológico regional. In: BRASIL-DNPM. Serra dos Carajás, folha SB-22-Z-A, estado do Pará. Brasília, DNPM-CPRM, Cap. 1. p. 17-50 (Programa de levantamentos geológicos básicos do Brasil)

BARROS, C.E.M.; DALL'AGNOL, R.; SOARES, A.D.V.; DIAS, G.S. 1994a. Metagabros de Águas Claras, Serra dos Carajás: petrografia, geoquímica e transformações metamórfico-hidrotermais. Acta Geol. Leopoldensia 40: 31-70

BARROS, C.E.M.; DALL'AGNOL, R.; VIEIRA, E.A.P.; MAGALHÃES, M.S. 1994b. Granito Serra dos Carajás: uma discussão sobre o seu potencial metalogenético para estanho com base em estudos na borda oeste do corpo. In: SIMP. GEOL. AMAZ., 4, Belém, 1996.. Extended Abstracts Bull... p. 307-309

COSTA, L.T.R. 1992. Aspectos sedimentológicos e estruturais da Formação Águas Claras nas proximidades do Córrego Águas Claras, Serra dos Carajás. (Undergraduate Geology Course Final Report, unpublished)

COSTA, J.B.S.; TEIXEIRA, N.P.; PINHEIRO, R.V.L.; BERMERGUY, R.L. 1990. Os sistemas estruturais transcorrentes do Cinturão Itacaiúnas na região de Curionópolis, leste do Estado do Pará. In: CONG. BRAS. GEOL., 36, Natal, 1990. Proceedings Natal, SBG, v. 2, p. 2345-2357

DALL'AGNOL, R.; LAFON, J-M.; MACAMBIRA, M.B. 1994. Proterozoic anorogenic magmatism in the Central Amazonian Province, Amazonian Craton: geochronological, petrological and geochemical aspects. Miner. Petrol. 50:113-138

DEER, W.A.; HOWIE, R.A.; ZUSSMAN, J. 1972. An introduction to rock-forming minerals. New York. Wiley \& Sons. 528p

DIAS, G.S.; MACAMBIRA, M.J.B.; DALL'AGNOL, R.; SOARES, A.D.V.; BARROS, C.E.M. 1996. Datação de zircão de sill de metagabro: comprovação da idade arqueana da Formação Águas Claras, Pará. In: SIMP. GEOL. AMAZ., 5, Belém, 1996. Bull. Extended Abstracts... p. 376-379

DOCEGEO (Distrito Amazônia). 1988. Revisão litoestratigráfica da Província Mineral de Carajás. In: CONG. BRAS. GEOL., 35, Belém, 1988. Província Mineral de Carajás - Litoestratigrafia e principais recursos minerais. Appended to the proceedings ... Belém, CVRD/SBG, p. 11-54

DOWLING, K. \& MORRINSON, K. 1989. Application of quartz textures to the classification of gold deposits using North Queensland examples. In: KEAYS, R.R;
RAMSAY, W.R.H.; GROVES, D.I. (Ed.) The geology of gold deposits: the perspective in 1988. Econ. Geol. Monograph 6, p. 342-355

GILBERT, F. PASCAL, M-L.; PICHAVANT, M. 1993. Solubility of gold in KC1 $(0.5 \mathrm{~m})$ solution under hydrothermal conditions $\left(350-450^{\circ} \mathrm{C}\right.$, SOObars). In: INTERN. SYMP. ON HYDROTHERMAL REACTIONS, 4, 1993. Proceedings, Nancy, p. 65-68

GILMER, A.L.; CLARK, K.F.; CONDIE, C.J.; HERNANDEZ, C.I.; FIGUEROA, S.J.I.; PORTER, E.W. 1988. Sierra de Santa Maria, Velardena mining district, Durango, Mexico. Econ. Geol, 83: 1802-1829

GOLDSTEIN, R.H. \& REYNOLDS, T.J. 1994. Systematics of fluid inclusions in diagenetic minerals. SEMP short course 31. Soc. Sed. Geology. 198p.

HENLEY, R.W.I 973. Solubility of gold in hydrothermal chloride solutions. Chem Geol., 11: $73-87$

HENRICH, C. A. 1990. The chemistry of hydrothermal tin (tungsten) ore deposition. Econ Geol. 85:457-481

HUSTON, D.L. \& LARGE, R.R. 1989. A chemical model for the concentration of gold in volcanogenic massive sulphide deposits. Ore Geol. Rev., 4: 171-200

MACHADO, N.; LINDENMEYER, Z.; KROCH, T.E.; LINDENMAYER, D. 1991. U-Pb geochronology of Archean magmatism and basement reactivation in the Carajás area, Amazon Shield, Brazil. Precambrian Res., 49: 327-354

MEDEIROS NETO, F.A. \& VILLAS, R.N. 1985. Geologia da jazida de Cu-Zn do Corpo 4E Pojuca, Serra dos Carajás. In: SIMP. GEOL. AMAZ., 2, Belém, 1985. Proceedings ... v.3, p. 97-112

MOUGEOT, R; RESPAUT, J.P; BRIQUEU, L; LEDRU, P; MILESI, J.P ; MACAMBIRA, M.J.; HUHN, S.B. 1996a. Geochronological constraints for the age of the Águas Claras Formation (Carajás Province, Pará, Brazil). In: CONG. BRAS. GEOL., 39, Salvador, 1996.. Extended abstracts Bull... , Salvador, SBG, v. 6, p $579-581$

MOUGEOT, R · RESPAUT, J.P ; BRIQUEU, L ; LEDRU, P ; MILESI, J P · LEROUGE, C.; HUHN, S.B.; MACAMBIRA, M.J. 1996b. Isotope geochemistry constraints for $\mathrm{Cu}$, Au mineralizations and evolution of the Carajás Province (Pará, Brazil). In: CONG. BRAS. GEOL., 39, Salvador, 1996. Extended abstracts Bull..., Salvador, SBG, v. 7, p. 321-324

NOGUEIRA, A.F.C.; TRUCKENBRODT, W.; PINHEIRO, R.V.L.; COSTA, J.B.S. 1992 Estudo faciológico e tectônico de sedimentos pré-cambrianos na região do Igarapé Águas Claras, Serra dos Carajás-PA. In: CONG. BRAS. GEOL., 37, São Paulo, 1992. Extended abstracts..., São Paulo, SBG, v. 2, p. 443-444

NOGUEIRA, A.F.C.; TRUCKENBRODT, W.; COSTA, J.B.S.; PINHEIRO, R.V.L. 1994 Análise faciológica e estrutural da Formação Águas Claras, Pré-cambriano da Serra dos Carajás, Pará. In: SIMP. GEOL. AMAZ., 4, Belém. Extended abstracts.. Belém, SBG, p. 363-364 
PINHEIRO, R.V.L.; NOGUEIRA, A.C.R.; COSTA, JBS. 1991. Superposição de transpressão na Sarados Carajás, Pará. In: SIMP. NAC. ESTUDOS TECTÔNICOS , 3, Rio Claro, 1991. Bulletin, SBG. p. 44-46

RIBEIRO, A.M. \& VILLAS, R.N. 1990. Estudo microtermométrico em cristais de quartzo de veios hidrotermais da Seqüência Bahia, Carajás, PA. In: CONG. BRAS. GEOL.,

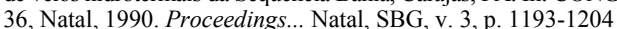

RIOS, F.J.; yiLLAS, R.N.; DALL'AGNOL, R. 1995. O granito Serra dos Carajás, Pará: I. Faties petrográficas e avaliação do potencial metalogenético para estanho no setor norte. Rev. Bros. Geoc., 25:20-31

RIPLEY, E.M. \& OHMOTO, H. 1977. Mineralogic, sulfur isotope, and fluid inclusion studies of the stratabound copper deposits at the Raul mine, Peru. Econ. Geol. 72: 1017-1041

ROMBERGER, S.B. 1990. Transport and deposition of gold in hydrothermal systems. In: ROBERT, F.; SHEARAN, P.A.; GREEN, S.B. (ed.), Greenstone belts and crustal evolution. NUNA conference volume, Van d'Or, Montreal. Geol. Assoc. Canada, p. 61-66

SHEPHERD, T.J.; RANKIN, A.H.; ALDERTON, D.H.M. 1985. A practical guide to fluid inclusion studies. London, Blakie. 273p.

SIBSON, R.H. 1987. Earthquake rupturing as a mineralizing agent in hydrothermal systems. Geology, 15:701-704

SIBSON, R.H.; ROBERT, F.; POULSEN, K.H. 1988. High-angle reverse faults, fluid-pressure cycling, and mesothermal gold-quartz deposits. Geology, 16: 551-555

SILVA, C.M.G. 1996. Oprospecto Águas Claras, Carajás (PA): alteração Mdrotermal e mineralização de sulfetos associada. Unpublished MSc. thesis, CG/UFPA
SOARES, A.D.V - SANTOS, A.B - E VIEIRA.A - BELLA, V.M.; MARTINS, L.P.B. 1994. Área Águas Claras: contexto geológico e mineralizações. In: SIMP. GEOL. AMAZ., 4, Belém, 1994. Extended abstracts... Belém, SBG.p. 379-382

STERNER, S.M.; HALL, D.L.; BODNAR, R.J. 1988. Synthetic fluid inclusions: V. Solubility relations in the system $\mathrm{NaCl}-\mathrm{KCl}-\mathrm{H} 20$ under vapor-saturated conditions. Geoch. Cosmoch. Acta, 52:989-1005

TEIXEIRA, W.; TASSINARI. C.C.G.; CORDANI, U.G.; KAWASHTTA, K. 1989. A review of the geochronology of the Amazon Craton: tectonic implications. Precambrian Res., 42:213-227

WEDEPOHL, K.L. 1976. Tungsten. In: WEDEPOHL, K.L.; TUREKIAN, K.K.; ZEMANN, J. (eds.). Handbook of Geochemistry, Berlin, Springer Verlag. Vol. II/4p. 74-A-1/74-O-2

WINTER, C.J. 1994. Geology and base-metal mineralization associated with Archean iron-formation in the Pojuca Corpo Quatro deposit, Carajás, Brazil. Unpublished $\mathrm{PhD}$ thesis, University of Southampton, 238p.

WIRTH, K.R ; GIBBS, A.K. OL SZEWSKI JR, W.J. 1986. U-Pb ages of zircons from the Grão-Pará Group and Serra dos Carajás granite, Pará, Brazil. Rev. Bras. Geoc. 16: 195-200

Manuscrito A-958 Recebido em 26 de fevereiro de 1998 Revisão do autor em 30 de março de 1998 Revisão aceita em 5 de abril de 1998 